Division of Geological \& Geophysical Surveys

RAW-DATA FILE 2014-16

\title{
Zircon U-Pb Age Data, Alaska Highway Corridor, Tanacross and Nabesna quadrangles, Alaska
}

by

Diana N. Solie, Paul O'Sullivan, Melanie B. Werdon, Larry K. Freeman,

Rainer J. Newberry, David J. Szumigala, and Trent D. Hubbard

$\$ 3.00$

July 2014

THIS REPORT HAS NOT BEEN REVIEWED FOR TECHNICAL CONTENT OR FOR CONFORMITY TO

THE EDITORIAL STANDARDS OF DGGS

Released by

STATE OF ALASKA

DEPARTMENT OF NATURAL RESOURCES

Division of Geological \& Geophysical Surveys

3354 College Road

Fairbanks, Alaska 99709-3707 



\section{TABLE OF CONTENTS}

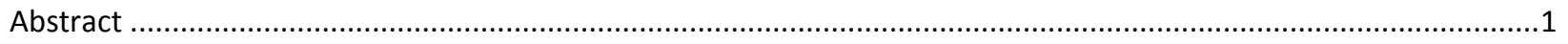

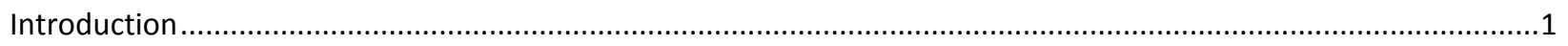

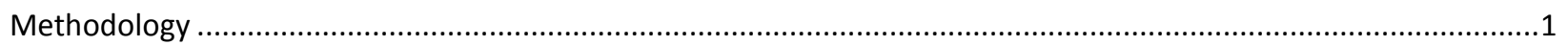

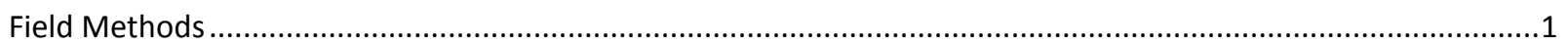

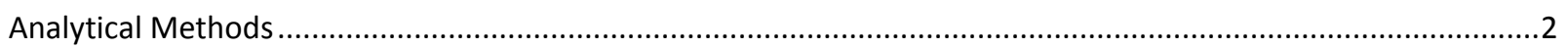

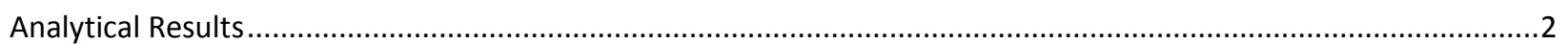

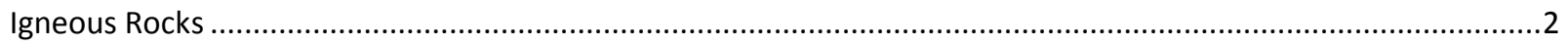

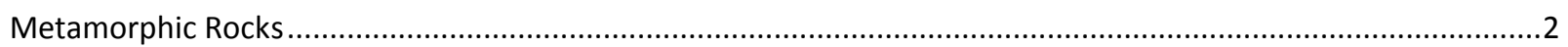

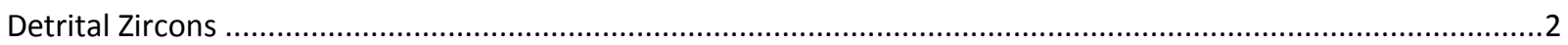

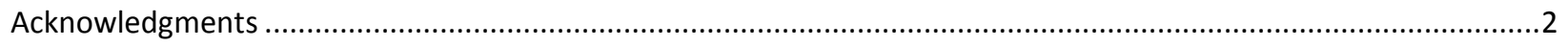

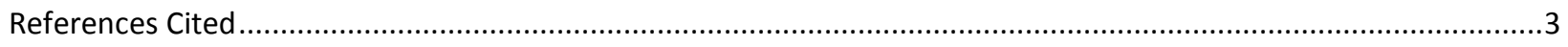

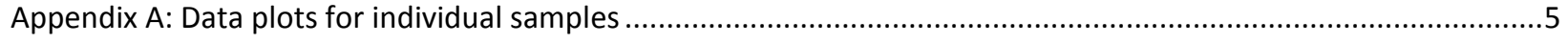

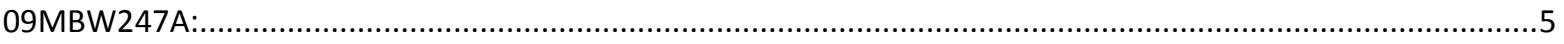

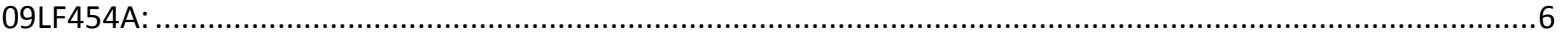

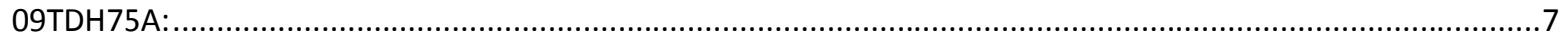

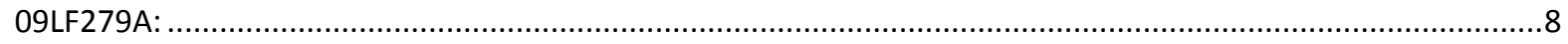

09Z213A:

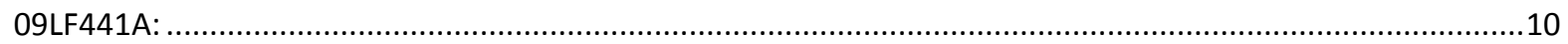

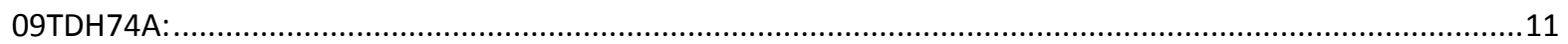

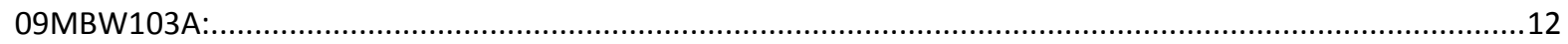

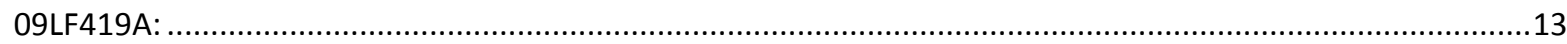

09Z172B:

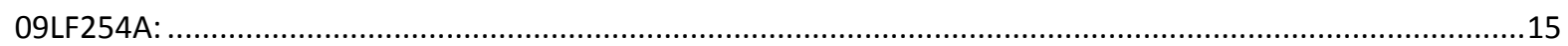

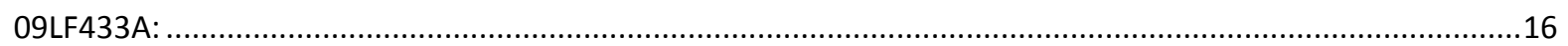

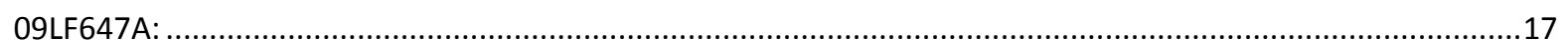

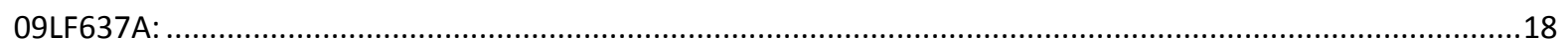

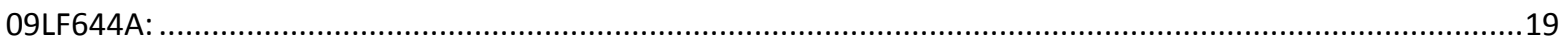

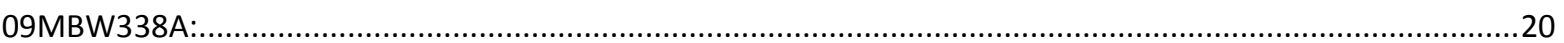

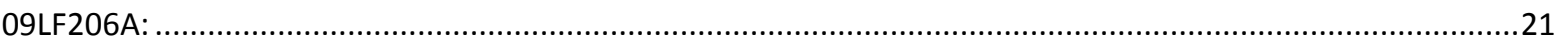

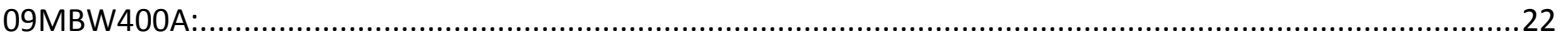

09MBW243A:

09LF233A: ……

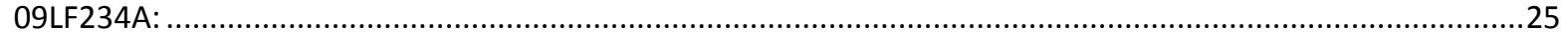


09RN242A:

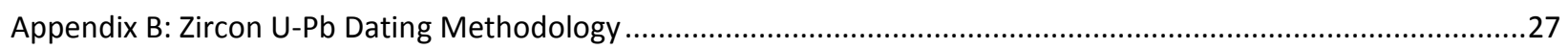

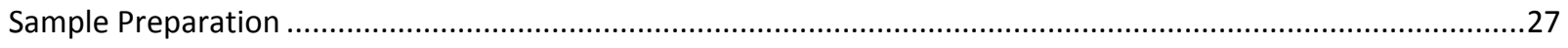

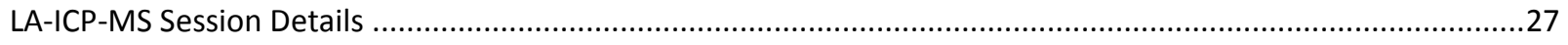

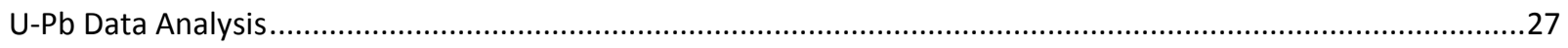

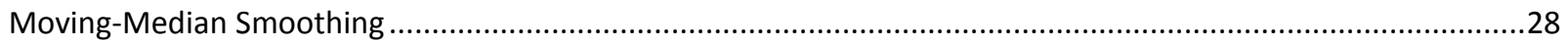

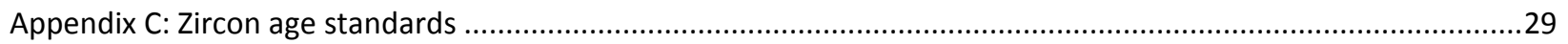




\title{
ZIRCON U-PB AGE DATA, ALASKA HIGHWAY CORRIDOR, TANACROSS AND NABESNA QUADRANGLES, ALASKA
}

\author{
by
}

\author{
Diana N. Solie ${ }^{1}$, Paul O'Sullivan², Melanie B. Werdon ${ }^{1}$, Larry K. Freeman ${ }^{1}$, \\ Rainer J. Newberry ${ }^{3}$, David J. Szumigala ${ }^{1}$, and Trent D. Hubbard ${ }^{1}$
}

\begin{abstract}
Twenty-two igneous and metamorphic rock samples were collected in a 20-km-long swath centered on the Alaska Highway between Tetlin Junction, Alaska, and the Canada border. The 15 felsic plutonic rock samples and one gabbro sample yield Cretaceous zircon U-Pb weighted-mean ages ranging from 95.7 Ma to 106.2 Ma. Zircons from a metadiorite yield a Triassic weighted-mean age of about $241.9 \mathrm{Ma}$. Metamorphic zircons from two samples with felsic igneous protoliths yield Mississippian weighted-mean ages of 351.7 Ma and 354.6 Ma. Detrital zircons from two metaconglomerates yield individual grain ages from $100 \mathrm{Ma}$ to 1,811 Ma, but are predominantly between 300 $\mathrm{Ma}$ and $345 \mathrm{Ma}$. Detrital zircons from a quartzite yield peaks at about 2,648 Ma, 1,946 Ma, and 1,807 Ma.
\end{abstract}

\section{INTRODUCTION}

The Alaska Division of Geological \& Geophysical Surveys (DGGS) conducted a multi-year project (from 2006 through 2010) studying the geology and geologic hazards along the Alaska Highway corridor (Solie and Burns, 2007). As part of the bedrock geologic mapping, samples were collected for geochronologic analyses using ${ }^{40} \mathrm{Ar} /{ }^{39} \mathrm{Ar}$, fission-track, and $\mathrm{U}-\mathrm{Pb}$ dating techniques. Summaries of analytical results appear on bedrock-geologic maps that are being published in three segments. This report supplies the supporting data for the U-Pb age results from the easternmost segment of the project, in the Tanacross and Nabesna quadrangles.

DGGS mapped the easternmost segment of the Alaska Highway corridor, from Tetlin Junction to the Canada border, in 2009. Twenty-two igneous and metamorphic rock samples were submitted to the Apatite to Zircon, Inc. laboratory (A2Z), where U-Pb age analysis was performed by Paul O'Sullivan in 2011. The resulting data, excerpted from the laboratory report, are presented in this publication. All data are available from the DGGS website (http://dggs.alaska.gov/pubs) at no charge.

\section{METHODOLOGY}

\section{Field Methods}

DGGS field geologists collected rock samples from the surface or within $0.5 \mathrm{~m}$ of the surface. Care was taken to collect fresh, unweathered samples representative of rock types in the map area. Locations were recorded using hand-held GPS units with an estimated horizontal accuracy of approximately $10 \mathrm{~m}$. Location coordinates for all dated samples are provided in an accompanying .csv file, in North American Datum of 1927 decimal degrees. This file also contains brief descriptions of each sample based on field observations.

\footnotetext{
${ }^{1}$ Alaska Division of Geological \& Geophysical Surveys, 3354 College Road, Fairbanks AK 99709-3707

${ }^{2}$ Apatite to Zircon, Inc., 1075 Matson Road, Viola, ID 83872-9709

3 University of Alaska Fairbanks, Department of Geology \& Geophysics, P.O. Box 755780, Fairbanks AK 99775-5780
} 


\section{ANALYTICAL METHODS}

DGGS submitted selected rock samples to Apatite to Zircon, Inc. in 2011. Paul O'Sullivan directed the processing and analyses of the samples in the A2Z laboratory. Laser ablation-inductively coupled plasma-mass spectrometry (LA-ICP-MS) analyses were performed at the Geoanalytical Laboratory, Washington State University, Pullman, Washington, U.S.A. Detailed discussion of laboratory techniques is provided in appendices to this report.

\section{ANALYTICAL RESULTS}

Twenty-two rock samples were analyzed. Data plots for each sample are provided in Appendix A, from youngest to oldest.

\section{IGNEOUS ROCKS}

Sixteen of the analyzed samples were igneous rocks. Fifteen were felsic plutonic rocks, either granite, granodiorite, or quartz monzonite; the other was gabbro. The weighted-mean age of all measurements from zircons in each igneous sample are recorded in the accompanying .csv table. All 16 ages fall within a span of about $10.5 \mathrm{Ma}$, between 95.7 $\pm 2.5 \mathrm{Ma}(09 \mathrm{MBW} 247 \mathrm{~A})$ and 106.2 $\pm 2.8 \mathrm{Ma}$ (09MBW338A). There is no apparent pattern to the age distribution across the map area, or correlation of rock type with age. The mafic igneous rock, a gabbro (09LF647A), yields a U-Pb weighted-mean age of $103.8 \pm 2.7 \mathrm{Ma}$.

\section{METAMORPHIC ROCKS}

A mafic sample from the southern map area, described in the field as diorite or possibly amphibolite with no foliation (09LF206A), yields an age distribution between 1,372 Ma and $114 \mathrm{Ma}$. We interpret these results to include lead loss yielding the younger measurements, and the weighted-mean age (based on 20 of 42 measurements) yields a Triassic age of $241.9 \pm 13.5 \mathrm{Ma}$.

Two metamorphosed felsic igneous rocks from the northern half of the map area were dated as lower Mississippian and upper Devonian. One, a metarhyolite (09MBW400A), yielded a weighted-mean age of $351.7 \pm$ 9.3 Ma based on 49 tightly grouped zircon measurements. The other, a granitic orthogneiss (09MBW243A), yielded a weighted-mean age of $354.6 \pm 9.3$ Ma based on 45 zircon measurements.

\section{DETRITAL ZIRCONS}

Detrital zircons from two metaconglomerate samples collected in the southern map area yield ages that are mostly younger than $350 \mathrm{Ma}$. Sample 09LF234A yielded two measurements around 1,800 Ma, and another around 225 Ma; the other 17 measurements are Carboniferous, between 300 Ma and 345 Ma. Sample 09LF233A yielded two zircon measurements of $100 \mathrm{Ma}$, and $321 \mathrm{Ma}$.

Detrital zircons from a quartzite collected about $3 \mathrm{~km}$ from the Canada border (09RN242A) yield a significantly older age distribution, with measurements ranging from 3,000 Ma to 1,030 Ma. The largest peak in the distribution (see plots in Appendix A) is at 1,807 Ma, with two smaller but prominent peaks at 1,946 Ma and 2,648 Ma.

\section{ACKNOWLEDGMENTS}

This project was supported by Alaska State Capital Improvement Project funds. Samples used in this report were collected by Larry Freeman, Melanie Werdon, David Szumigala, and Trent Hubbard of DGGS; and Rainer Newberry 
of the University of Alaska Fairbanks Department of Geology and Geophysics. Margaret Donelick and Jim McMillan (A2Z) provided technical assistance with sample preparation; Charles Knaack (Washington State University) provided technical assistance with LA-ICP-MS data collection; Paul O'Sullivan and Ray Donelick (A2Z) provided valuable assistance with LA-ICP-MS data interpretation.

\section{REFERENCES CITED}

Black, L.P., Kamo, S.L., Allen, C.M., Davis, D.W., Aleinikoff, J.N., Valley, J.W., Mundil, Roland, Campbell, I.H., Korsch, R.J., Williams, I.S., and Foudoulis, Chris, 2004, Improved ${ }^{206} \mathrm{~Pb} /{ }^{238} \mathrm{U}$ microprobe geochronology by the monitoring of trace-element-related matrix effect-SHRIMP, ID-TIMS, ELA-ICP-MS, and oxygen isotope documentation for a series of zircon standards: Chemical Geology, v. 205, p. 15-140.

Chang, Zhaoshan, Vervoort, J.D., McClelland, W.C., and Knaack, Charles, 2006, U-Pb dating of zircon by LA-ICP-MS: Geochemistry, Geophysics, Geosystems, American Geophysical Union, v. 7, no. 5, 14 p., doi:10.1029/2005GC001100.

Chew, D.M., and Donelick, R.A., 2012, Combined apatite fission track and U-Pb dating by LA-ICP-MS and its application in apatite provenance analysis: Mineralogical Association of Canada Short Course, v. 42, p. 219-247.

Donelick, R.A, O'Sullivan, P.B., and Ketcham, R.A., 2005, Apatite fission-track analysis: Reviews in Mineralogy and Geochemistry, Mineralogical Society of America, v. 58, p. 49-94.

Gehrels, G.E., Valencia, V.A., and Ruiz, J., 2008, Enhanced precision, accuracy, efficiency, and spatial resolution of U$\mathrm{Pb}$ ages by laser ablation-multicollector-inductively coupled plasma-mass spectrometry: Geochemistry Geophysics Geosystems, American Geophysical Union, v. 9, 13 p.

Kuiper, K.F., Deino, A., Hilgen, P.J., Krijgsman, W., Renne, P.R., and Wijbrans, J.R., 2008, Synchronizing rock clocks of Earth history: Science, v. 320, p. 500-504.

Lanphere, M.A., and Baadsraard, H., 2001, Precise K-Ar, ${ }^{40} \mathrm{Ar} /{ }^{39} \mathrm{Ar}$, Rb-Sr and U-Pb mineral ages from the $27.5 \mathrm{Ma}$ Fish Canyon Tuff reference standard: Chemical Geology, v. 175, p. 653-671.

Paces, J.B., and Miller, J.D., 1993, Precise U-Pb ages of Duluth Complex and related mafic intrusions, northeastern Minnesota-Geochronological insights to physical, petrogenic, paleomagnetic, and tectonomagmatic processes associated with the $1.1 \mathrm{Ga}$ Midcontinent Rift System: Journal of Geophysical Research, v. 98, no. B8, p. 13,99714,013 .

Paton, C., Woodhead, J.D., Hellstrom, J.C., Hergt, J.M., Greig, A., and Maas, R., 2010, Improved laser ablation U-Pb zircon geochronology through robust downhole fractionation correction: Geochemistry, Geophysics, Geosystems, v. 11, no. Q0AA06, doi:10.1029/2009GC002618.

Renne, P.R., Swisher, C.C., Deino, A.L., Karner, D.B., Owens, T.L., and DePaolo, D.J., 1998, Intercalibration of standards, absolute ages and uncertainties in ${ }^{40} \mathrm{Ar} /{ }^{39} \mathrm{Ar}$ dating: Chemical Geology, v. 45, p. 117-152.

Solie, D.N., and Burns, L.E., 2007, Alaska Highway corridor geology and geophysics: Alaska GeoSurvey News, v. 10, no. 1, p. 1-4.

Steiger, R.H., and Jäger, E., 1977, Subcommission on geochronology-Convention on the use of decay constants in geo- and cosmochronology: Earth and Planetary Science Letters, v. 36, p. 369-371.

Zhang, M., Ewing, R.C., Boatner, L.A., Salje, E.K.H., Weber, W.J., Daniel, P., Zhang, Y., and Farnan, I., 2009, Pb* irradiation of synthetic zircon ( $\left.\mathrm{ZrSiO}_{4}\right)$; Infrared spectroscopic study-Reply: American Mineralogist, v. 94, p. 856-858. 
RDF 2014-

P a g e | 4 
APPENDIX A: DATA PLOTS FOR INDIVIDUAL SAMPLES

09MBW247A:
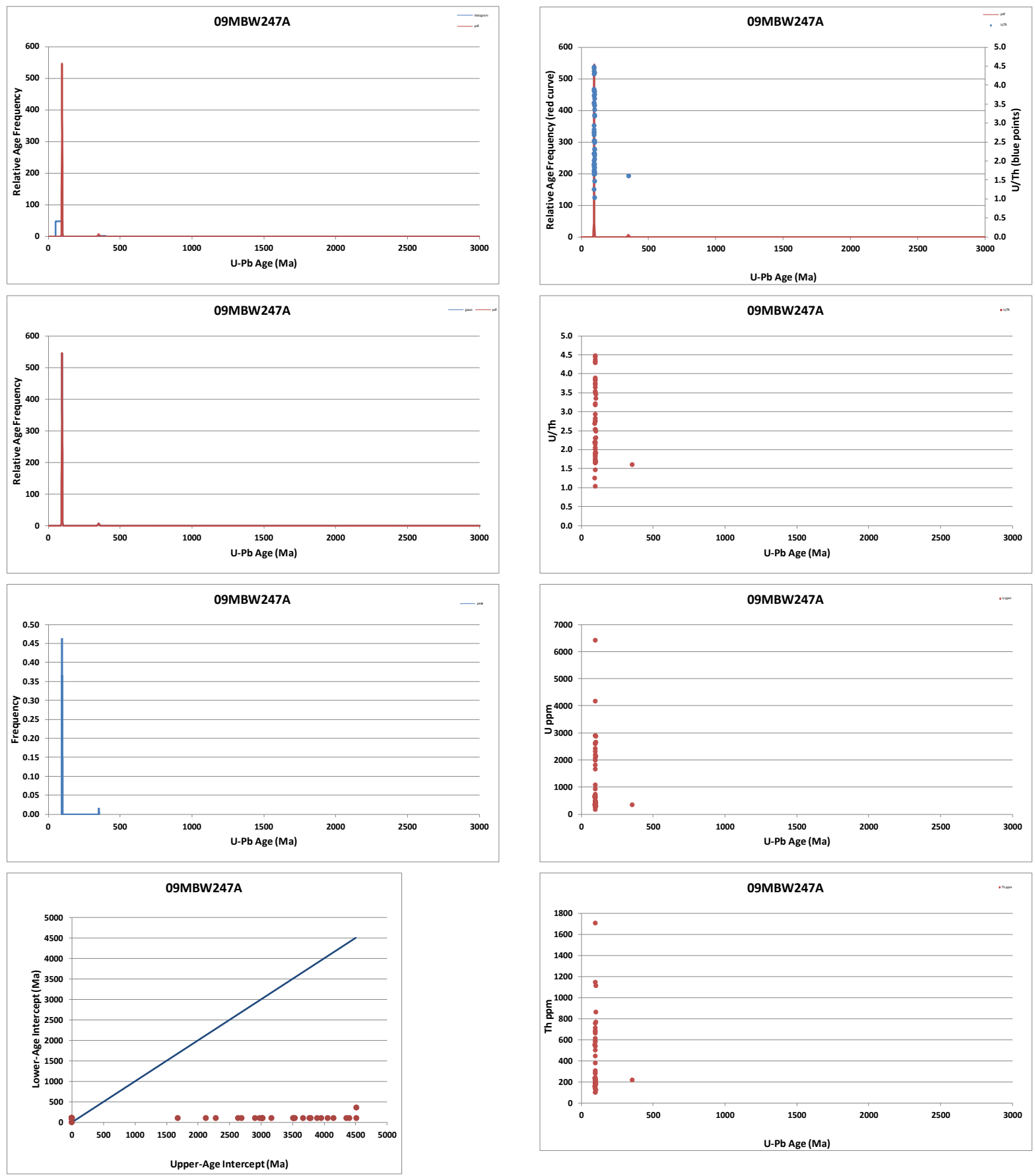
09LF454A:
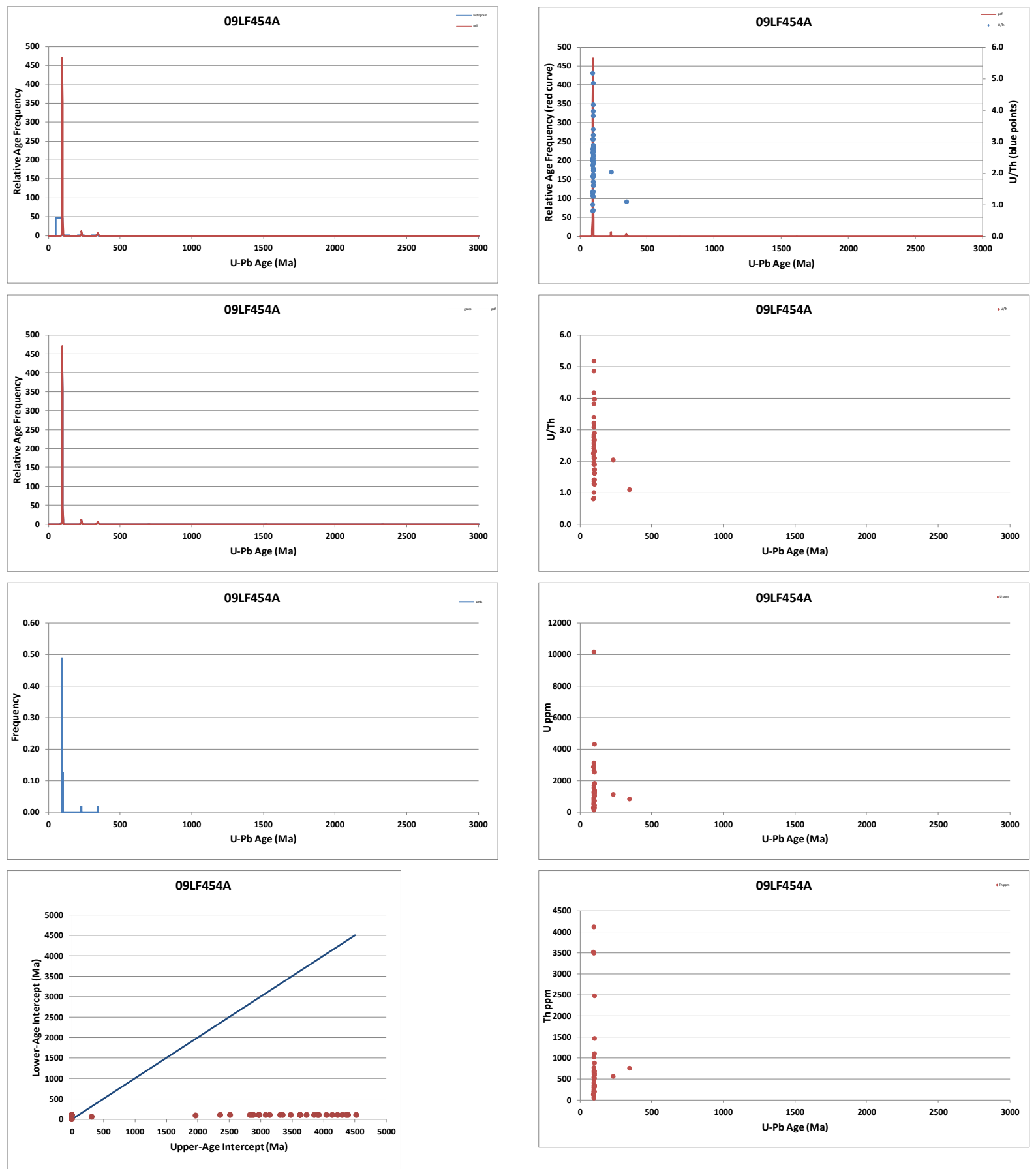
09TDH75A:
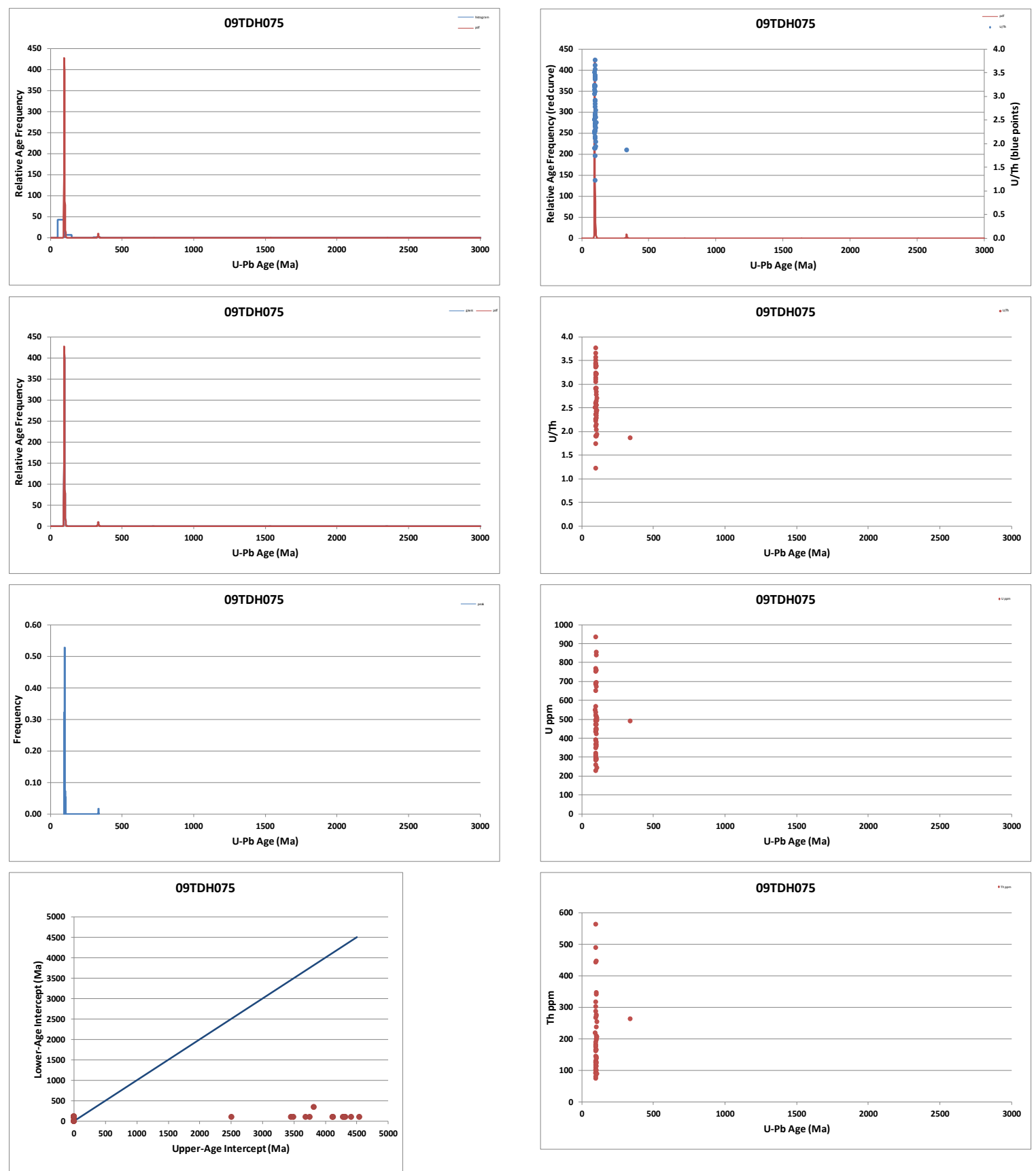
09LF279A:
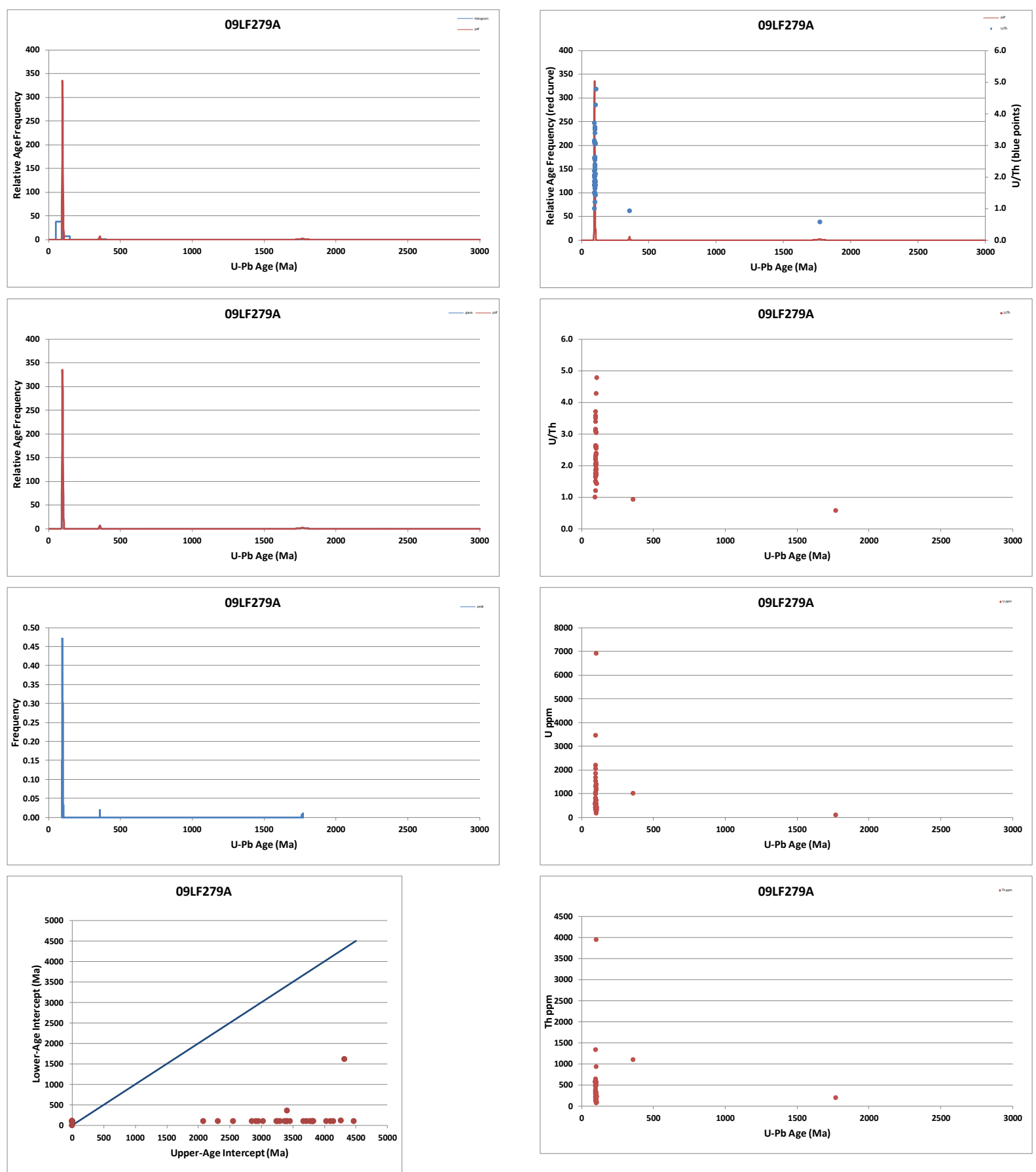
09Z213A:
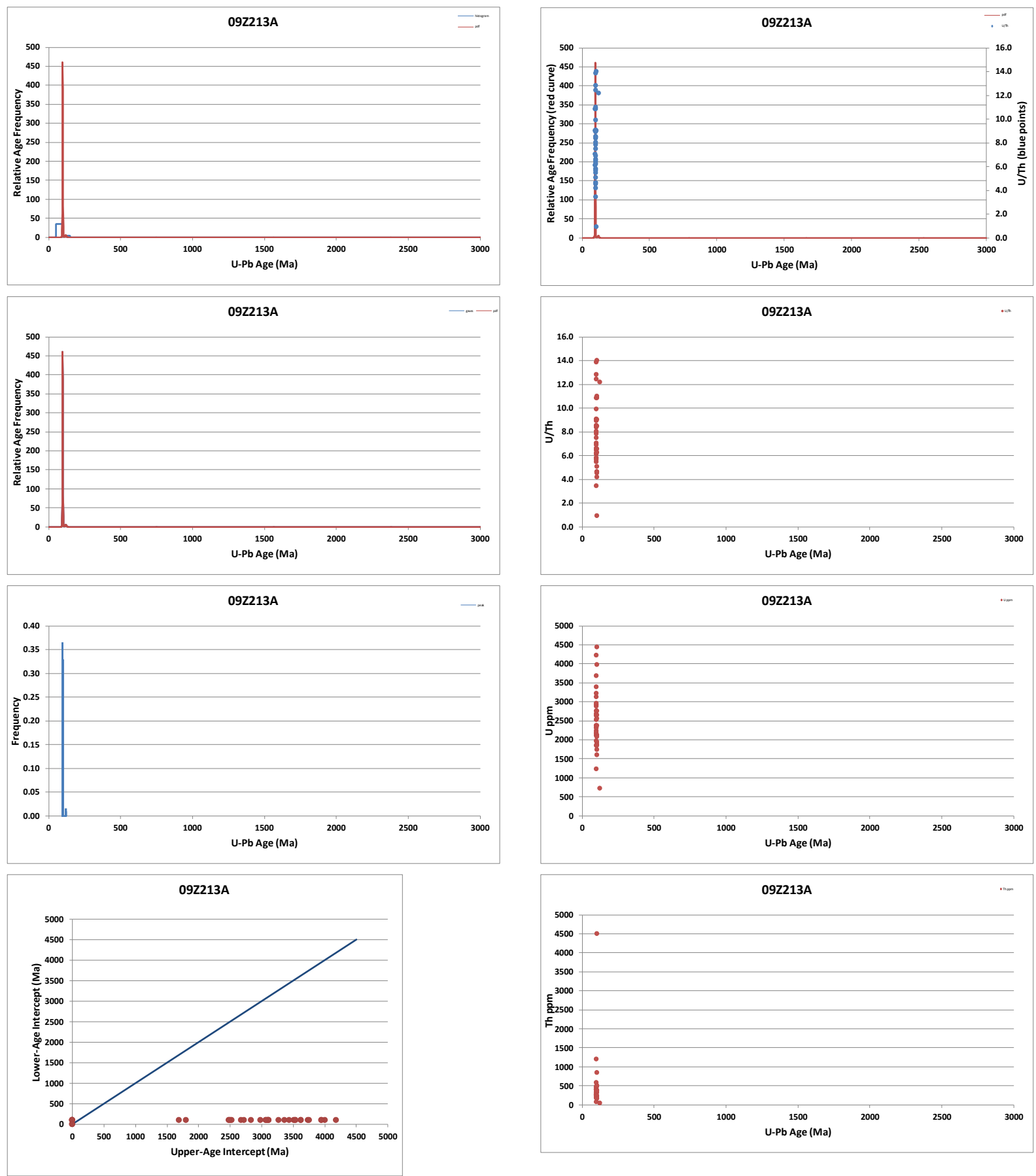
09LF441A:
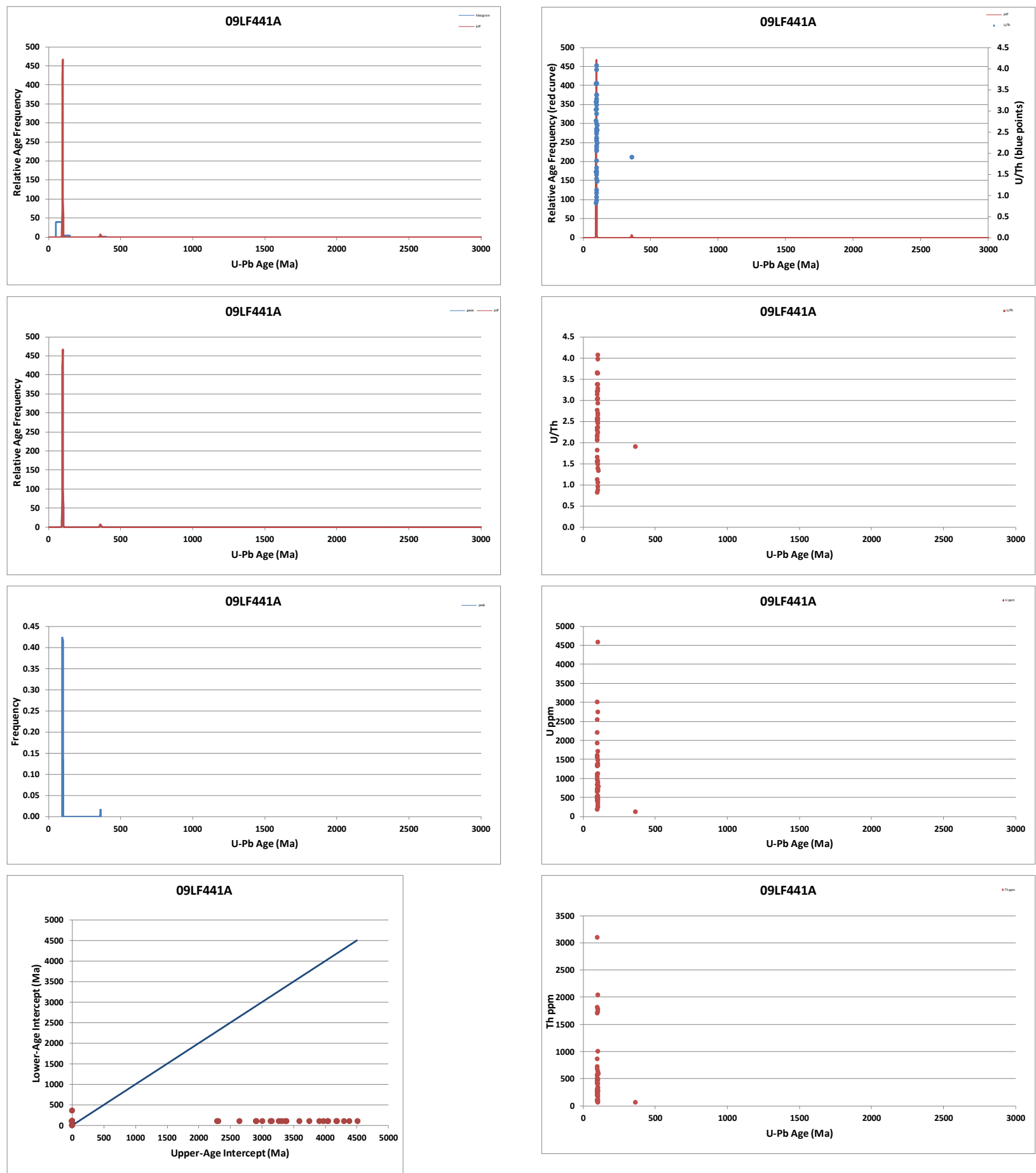
09TDH74A:
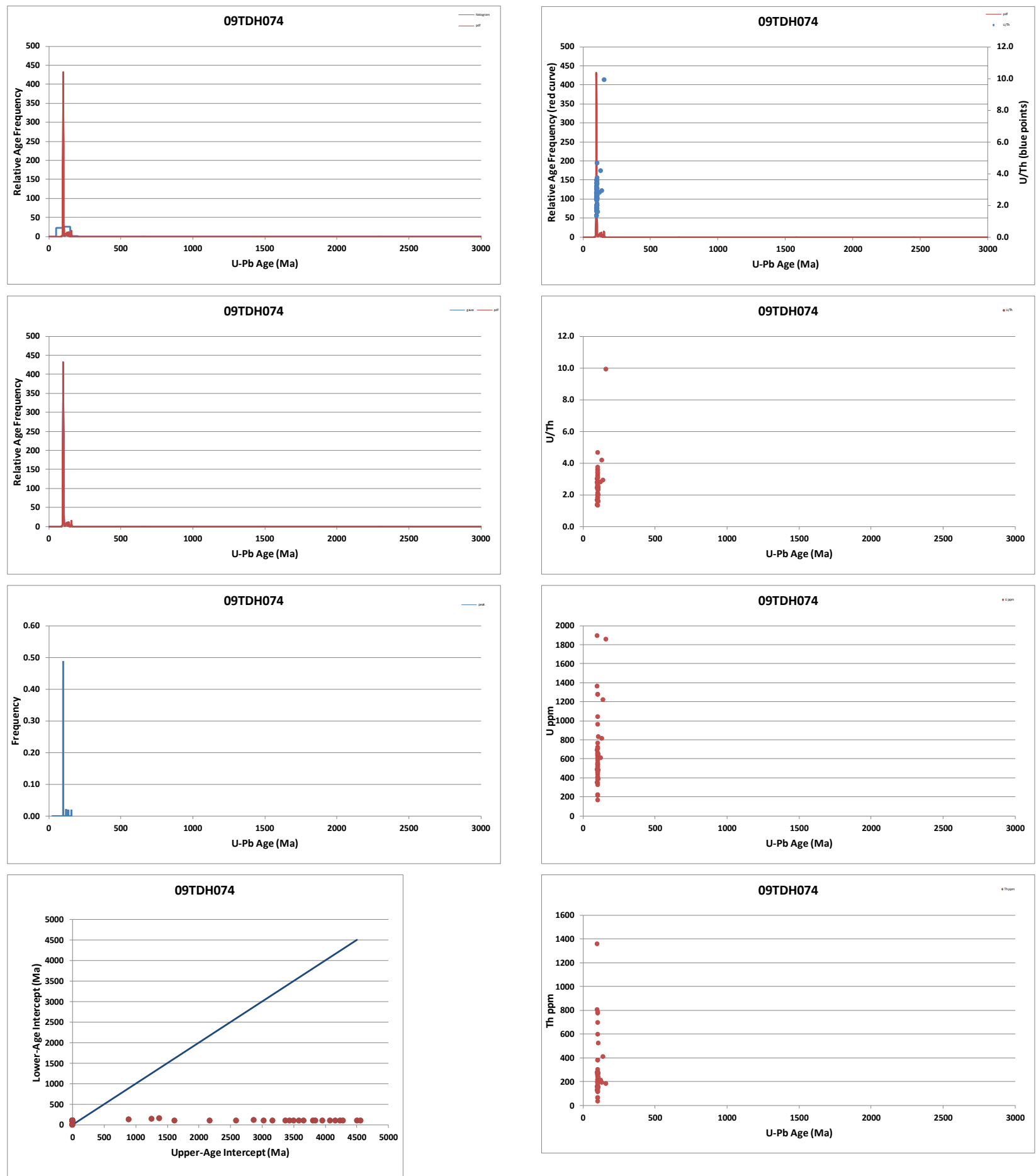
09MBW103A:
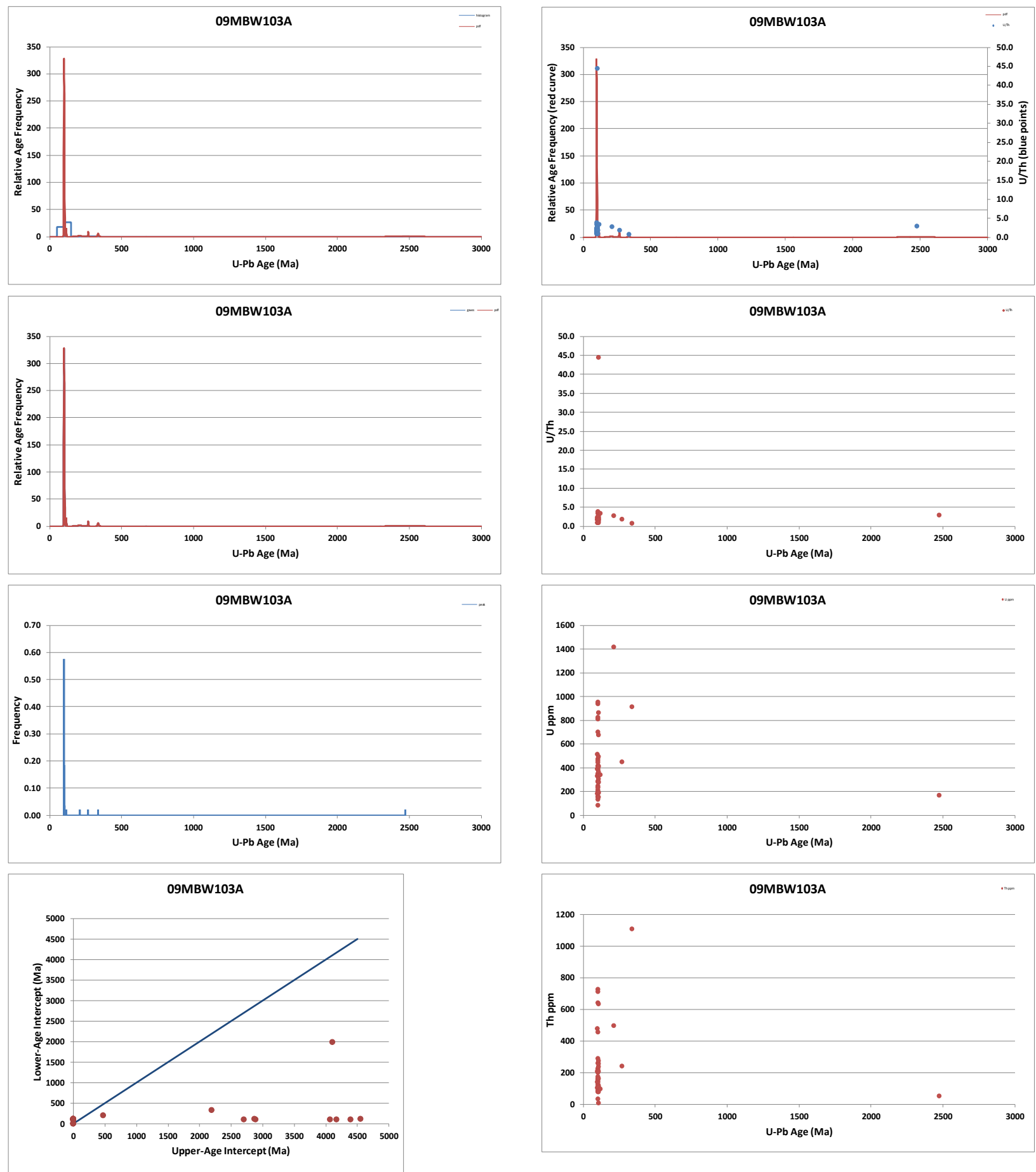
09LF419A:
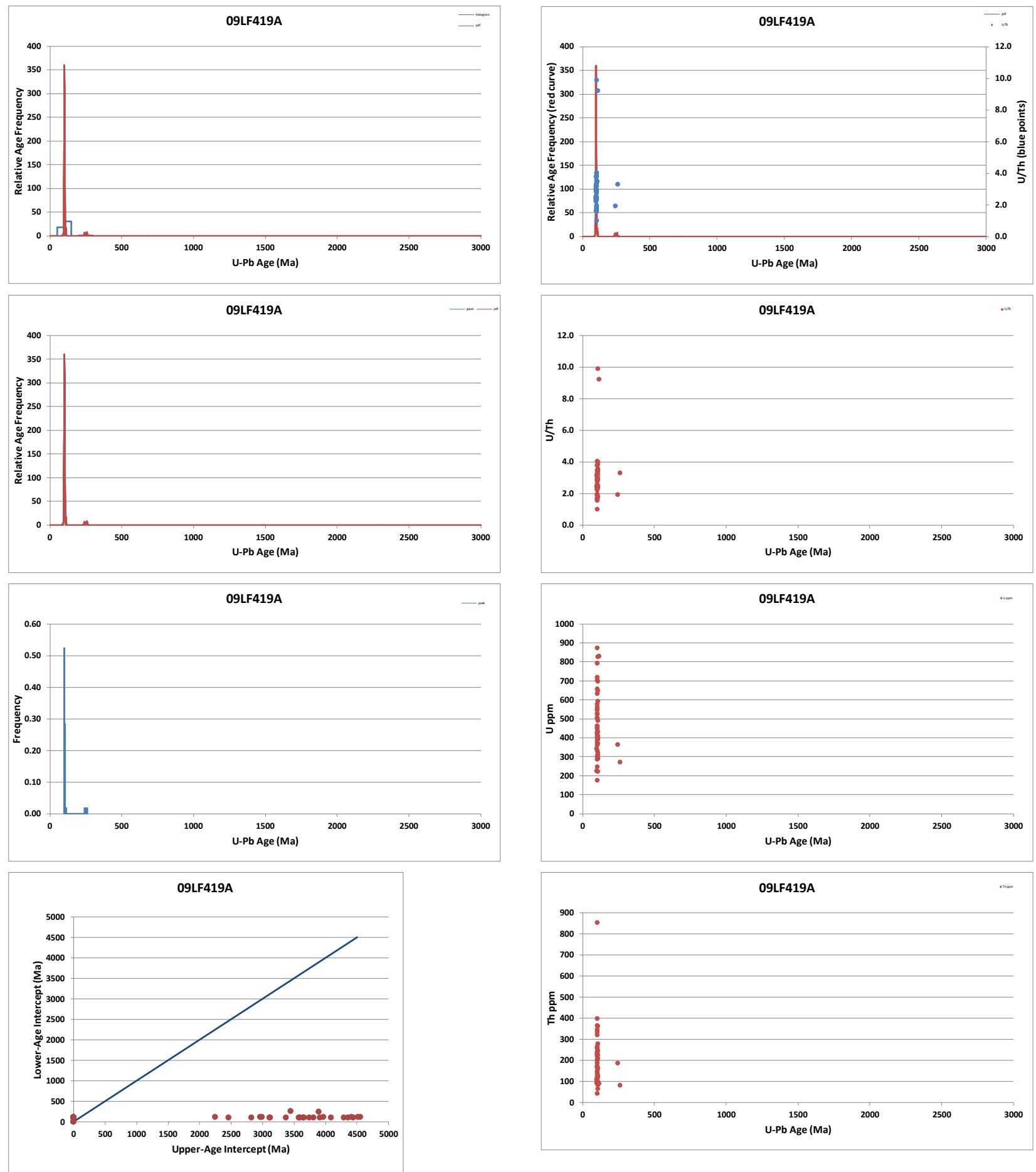
09Z172B:
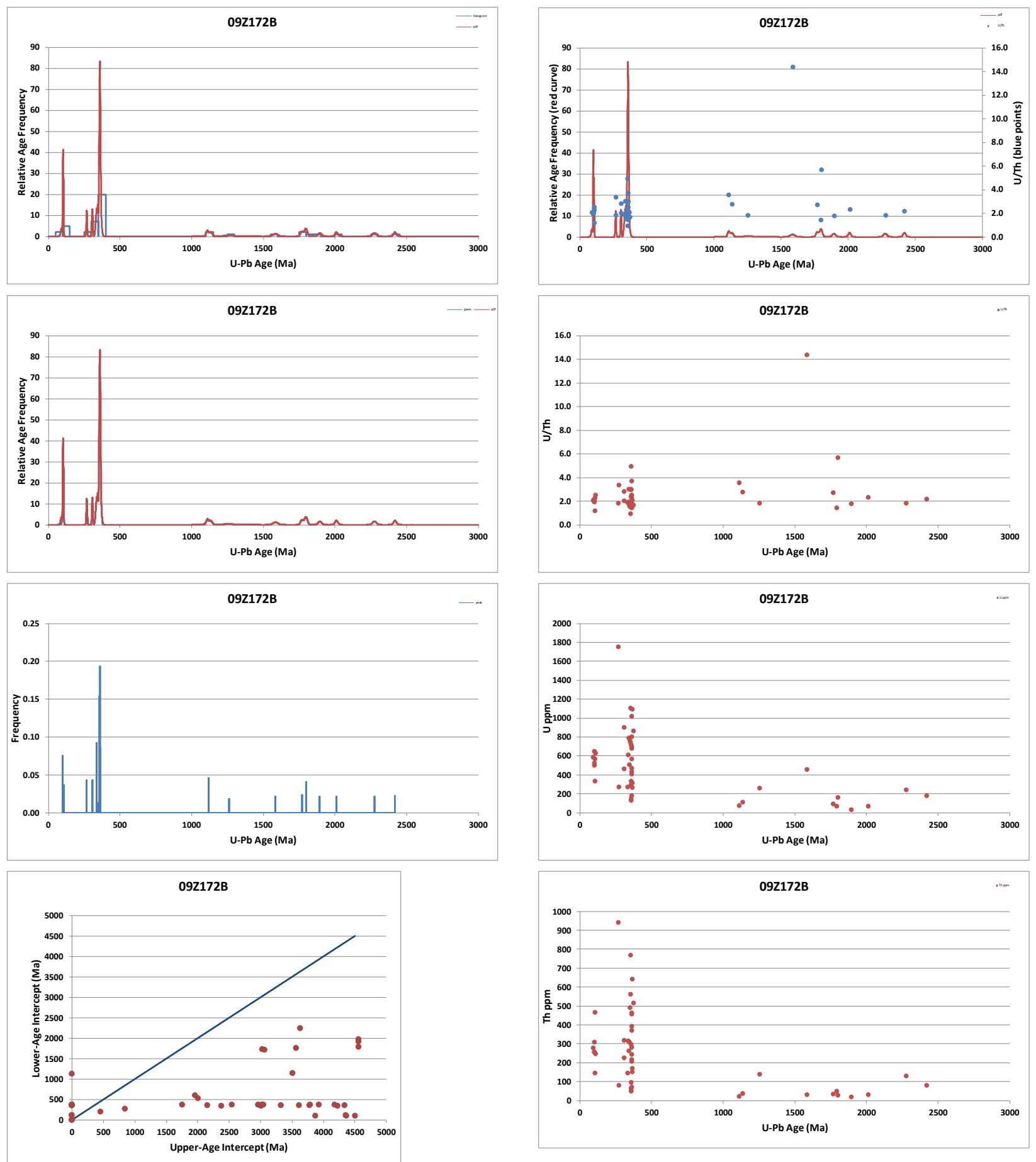
09LF254A:
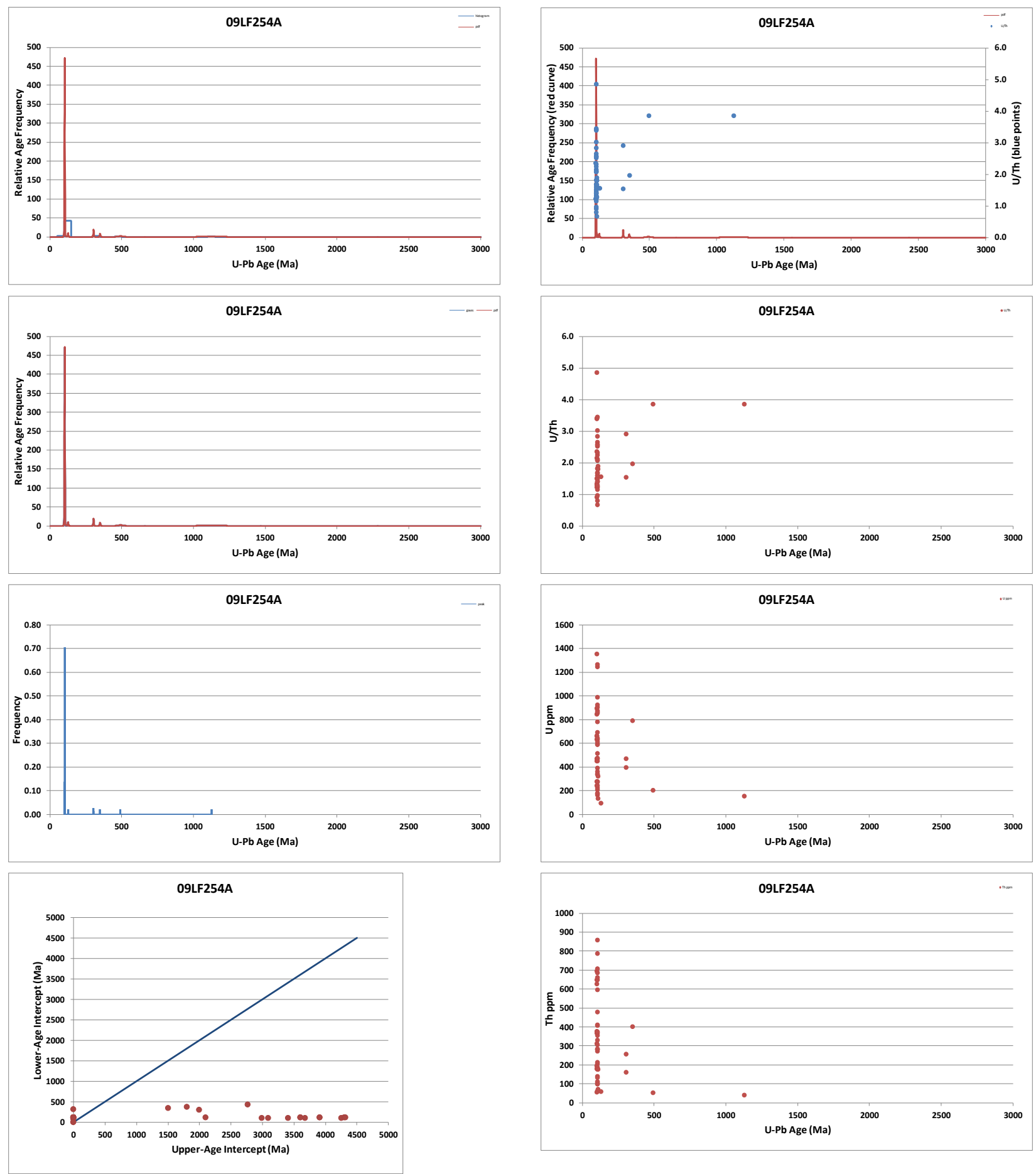
09LF433A:
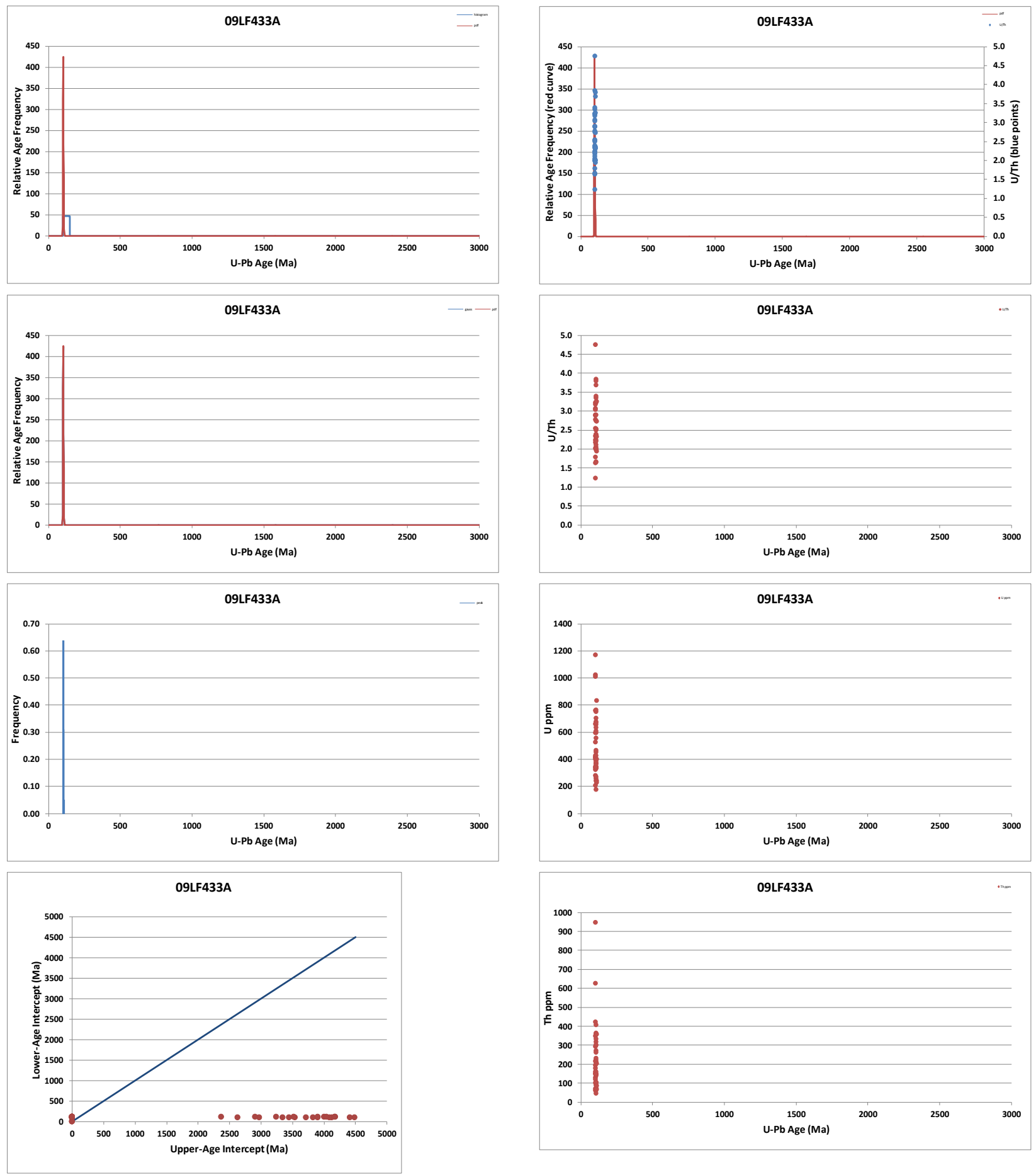
09LF647A:
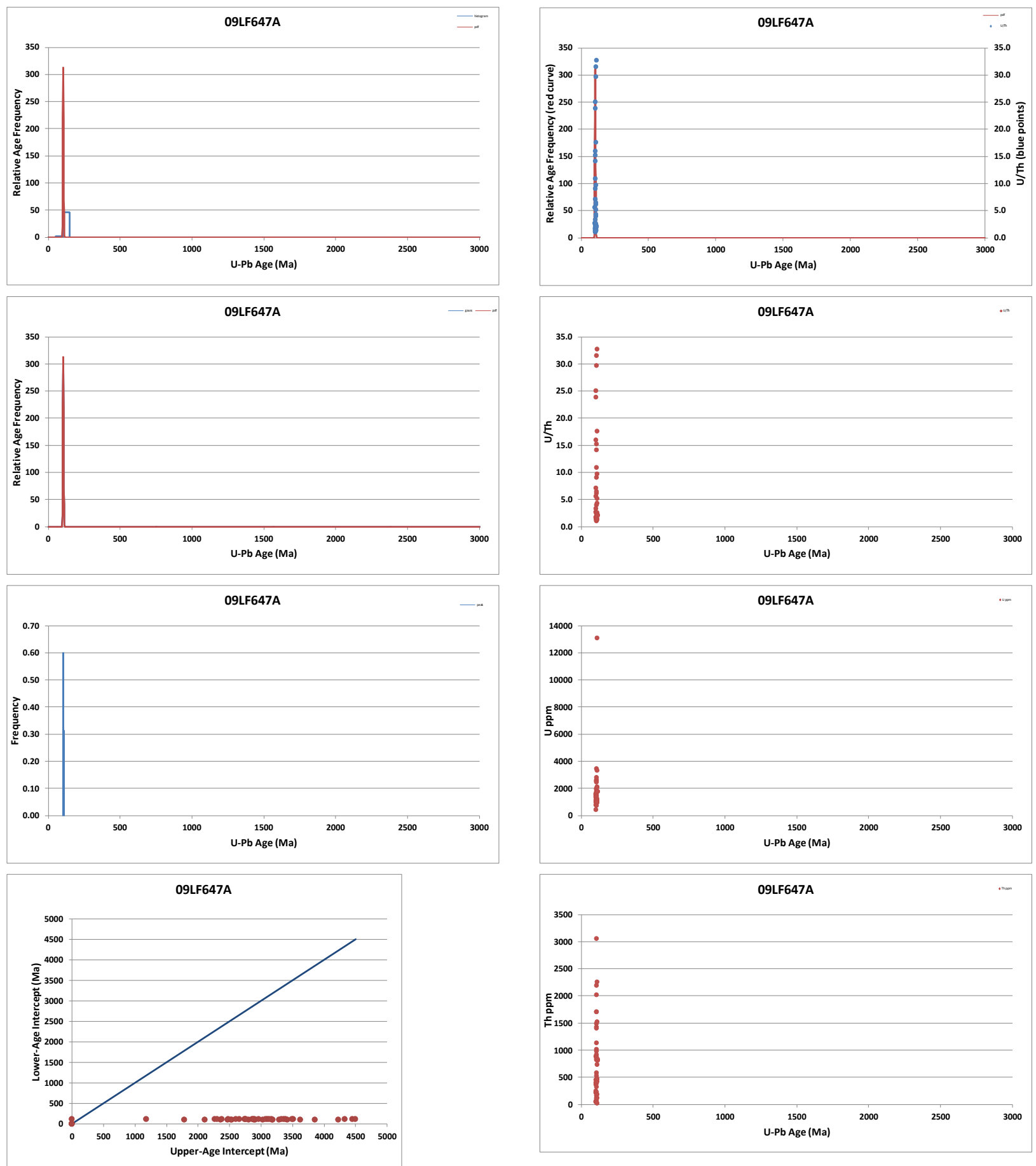
09LF637A:
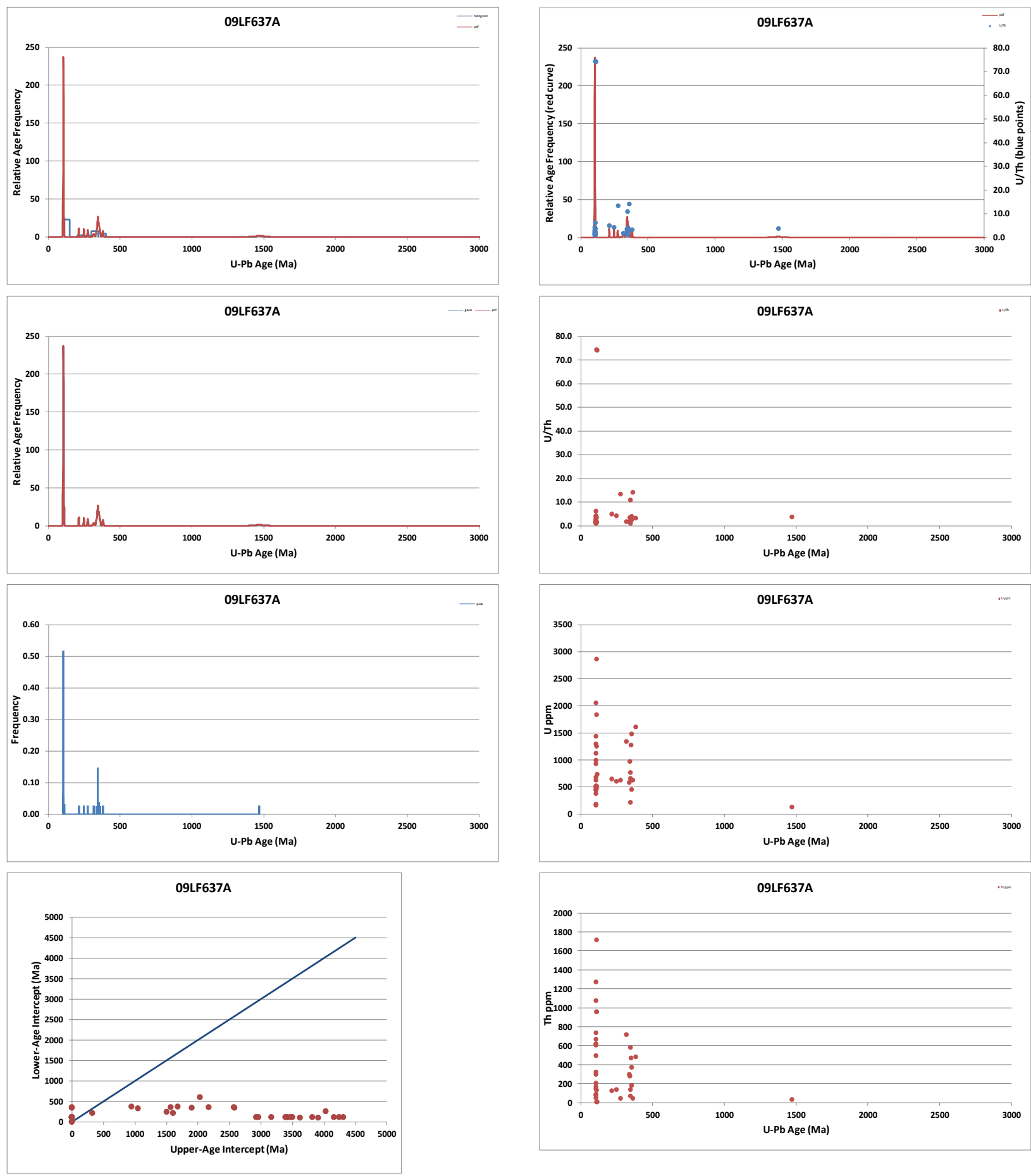
09LF644A:
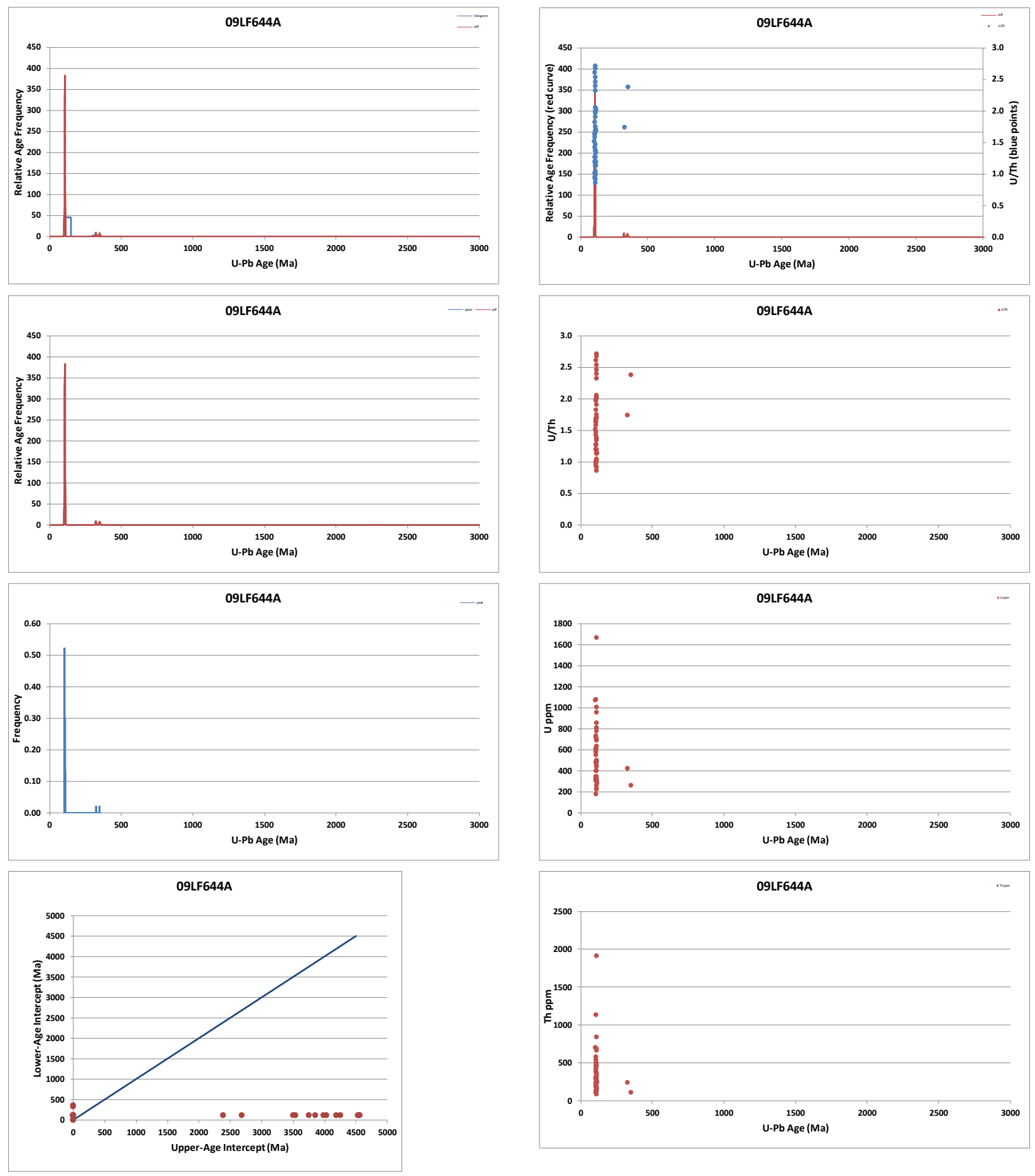
09MBW338A:
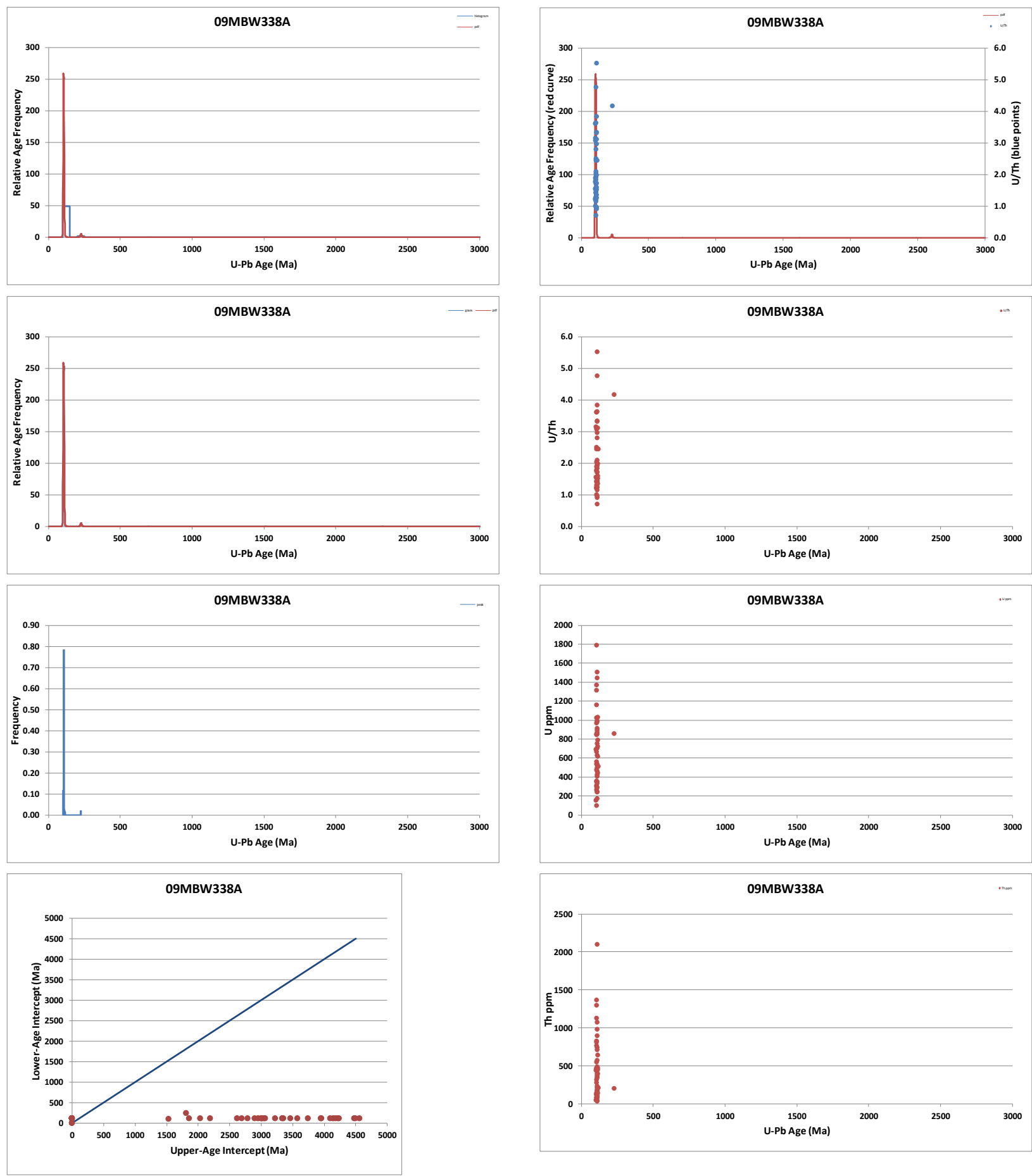
09LF206A:
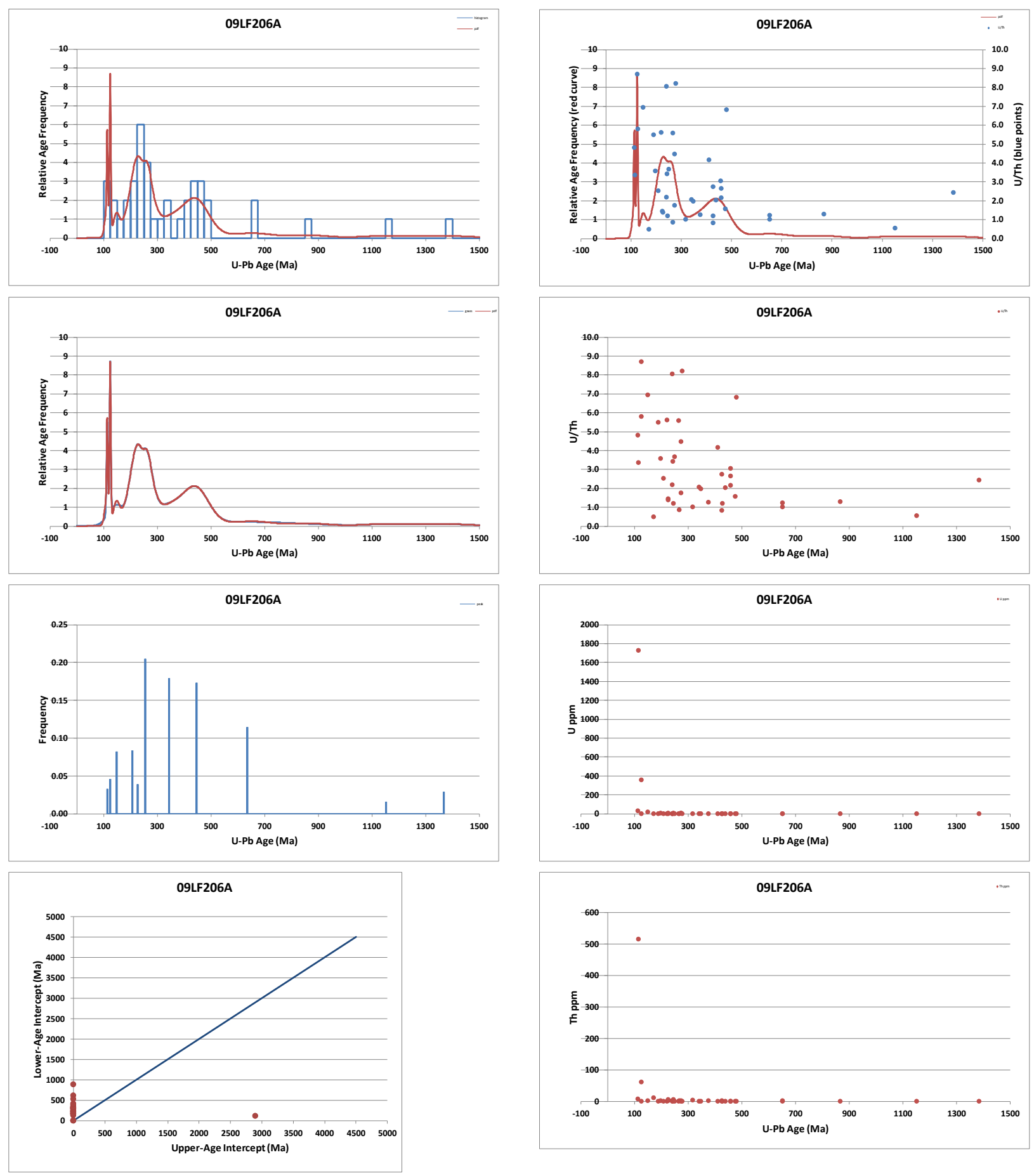
09MBW400A:
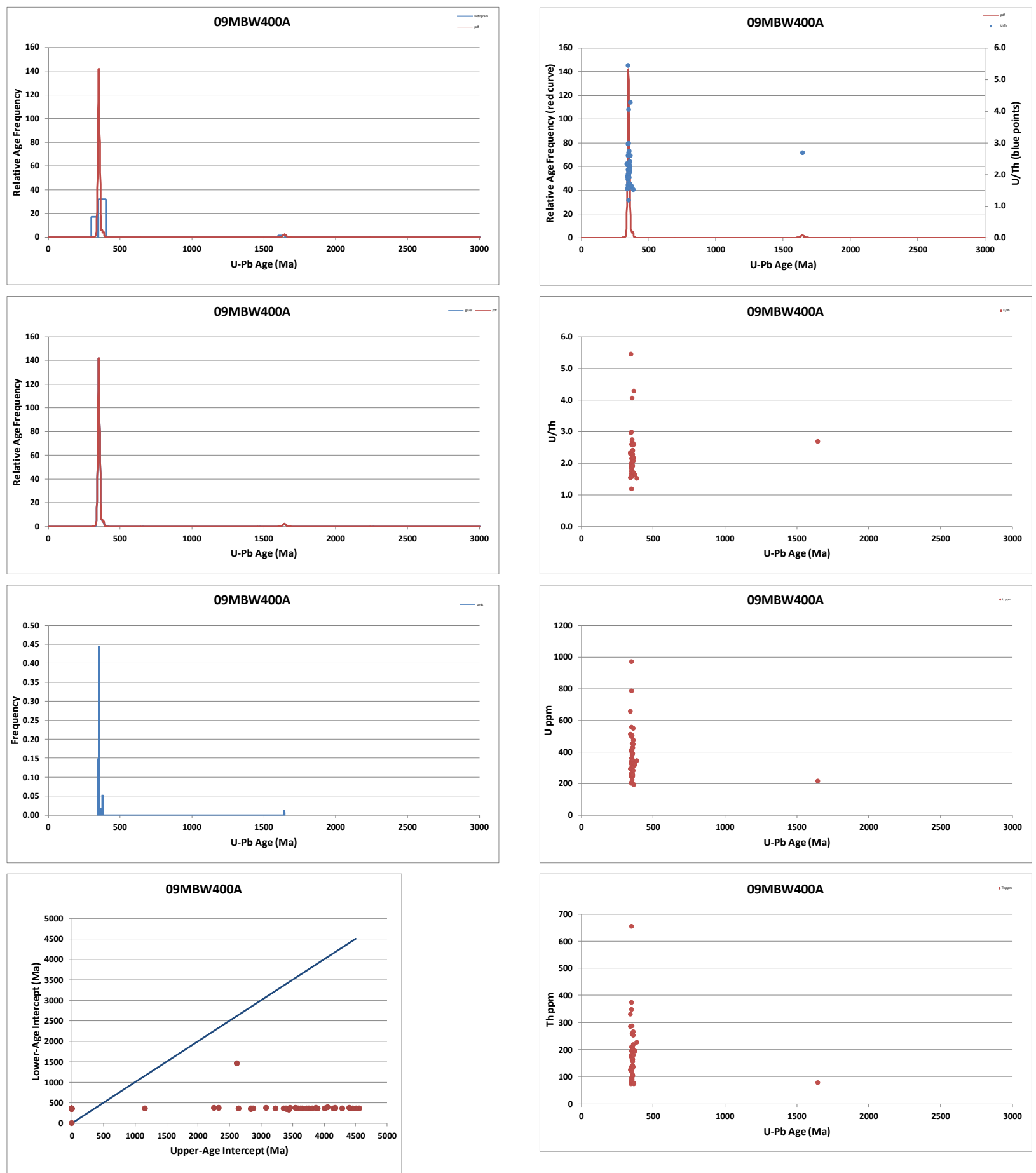
09MBW243A:
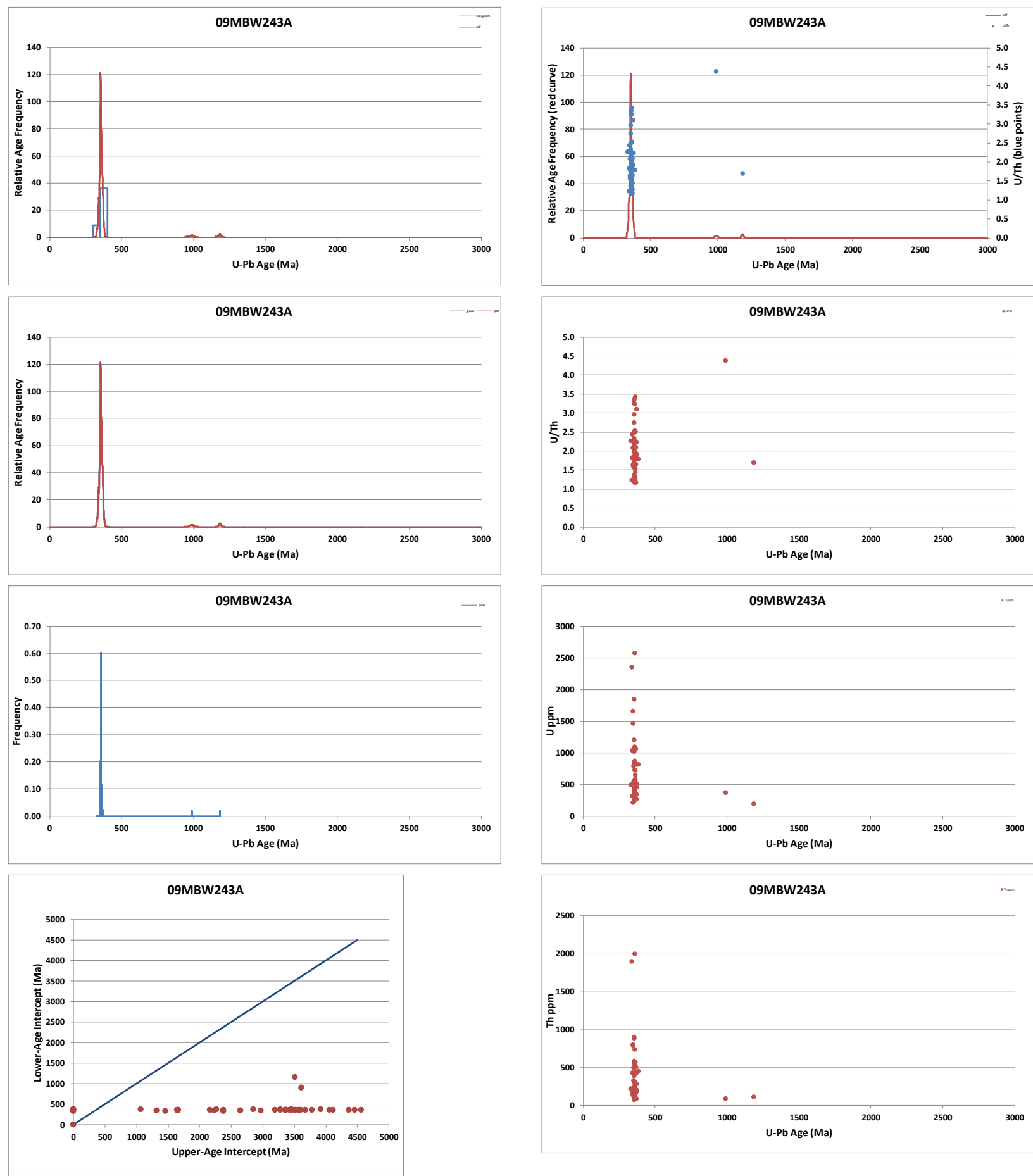
09LF233A:
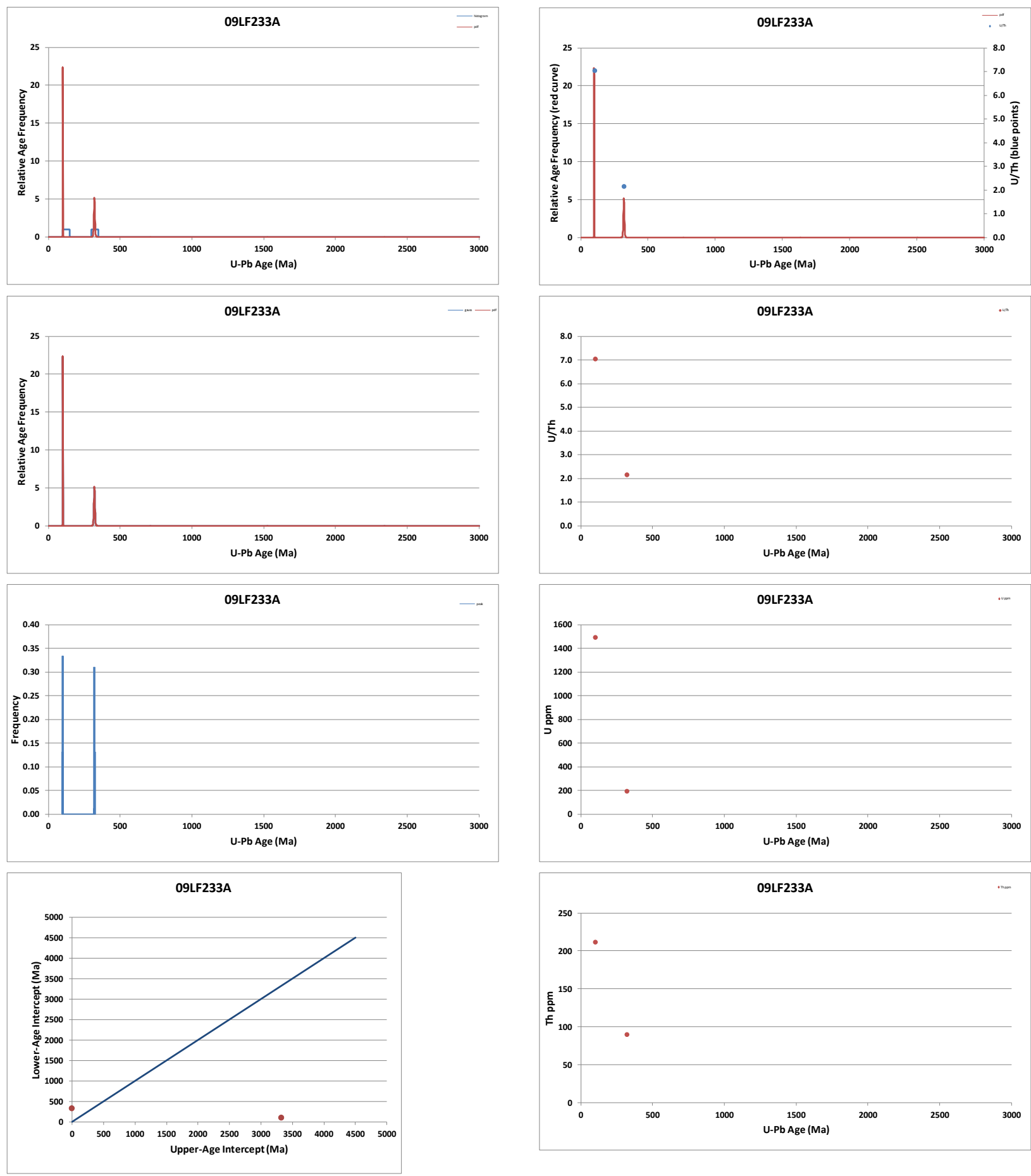
09LF234A:
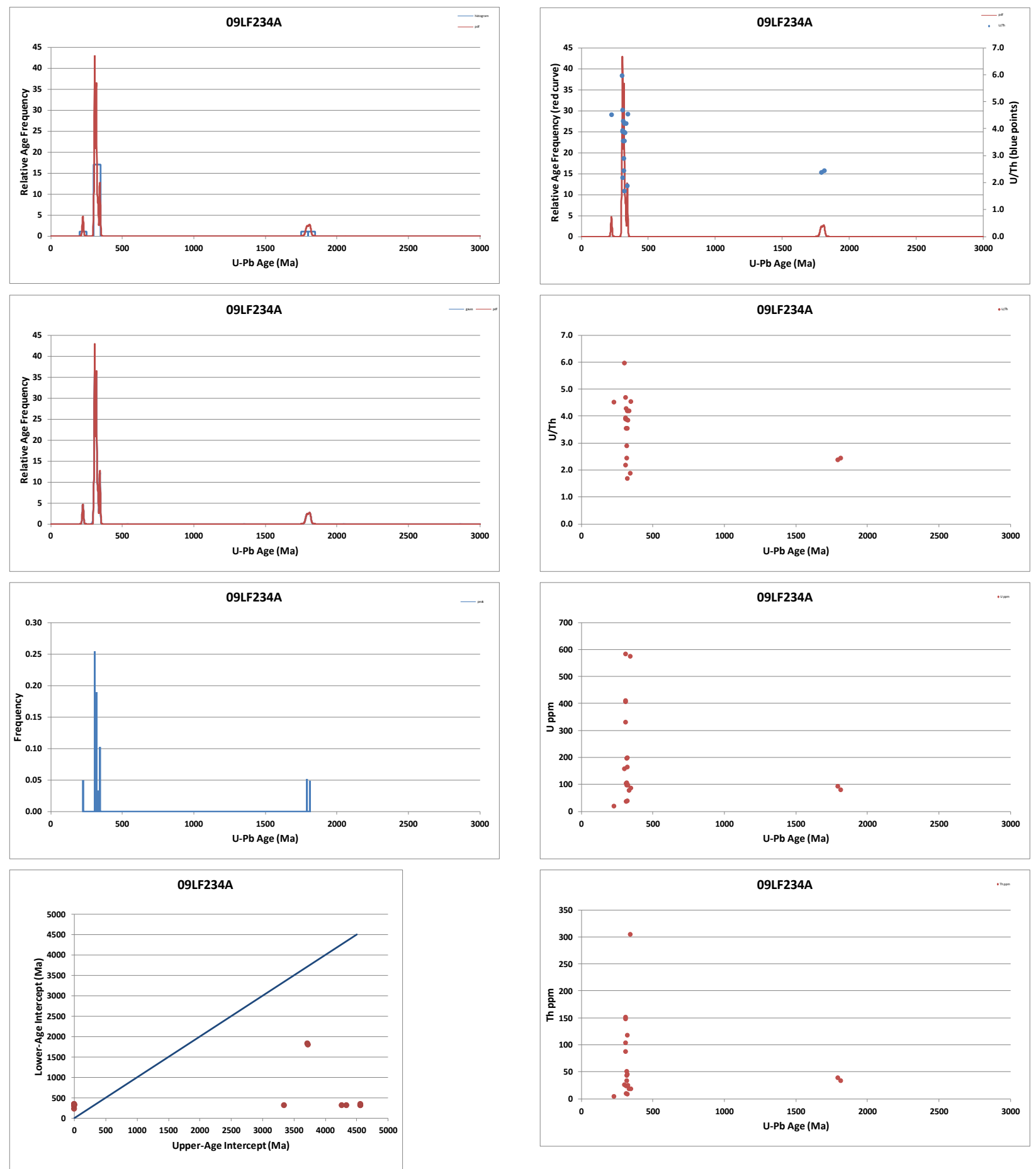
09RN242A:
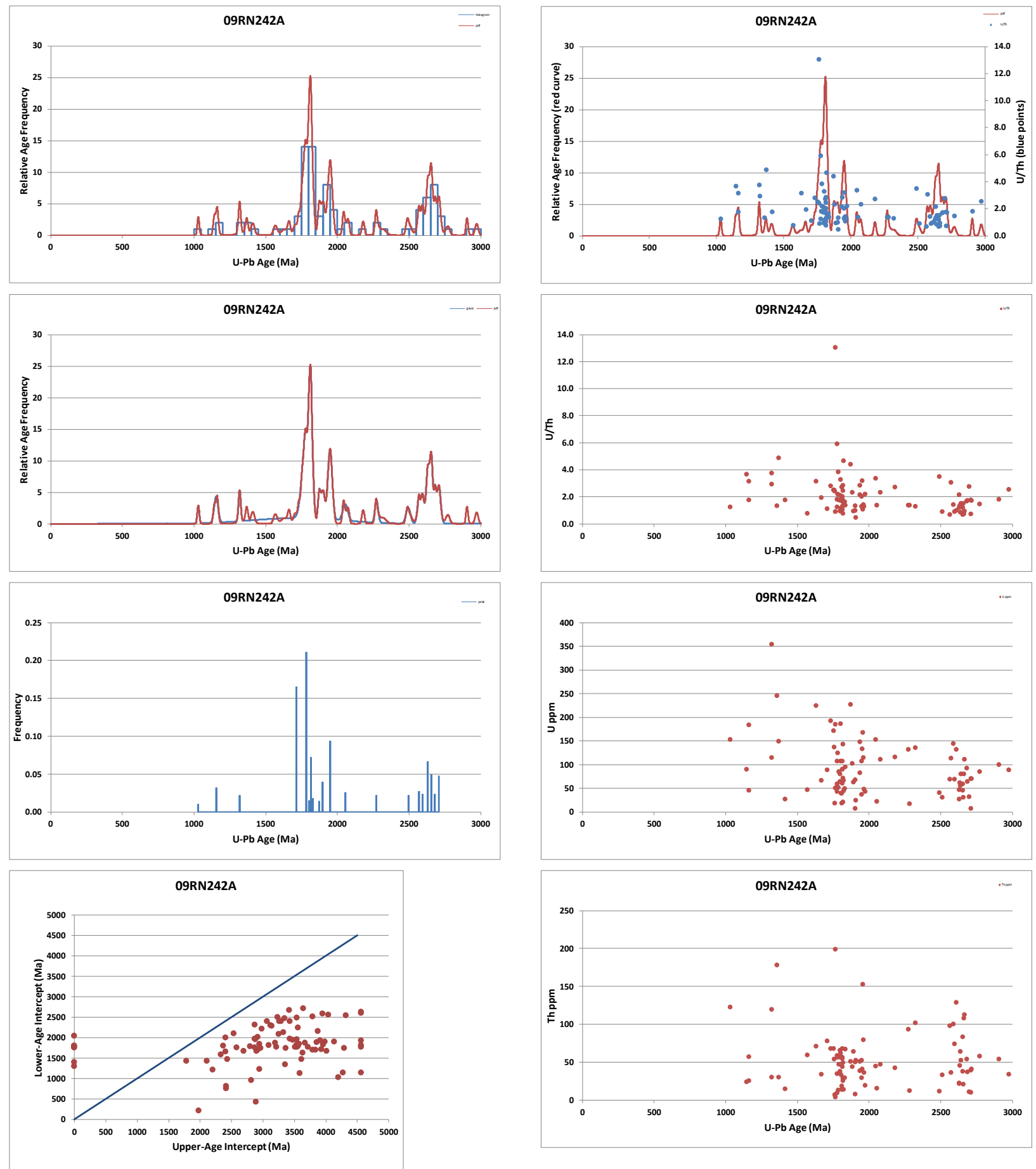


\section{APPENDIX B: ZIRCON U-PB DATING METHODOLOGY}

\section{Sample Preparation}

Zircon grains were isolated and prepared for Laser Ablation-Inductively Coupled Plasma-Mass Spectrometry (LA-ICPMS) analysis using standard procedures combined with specific customized procedures described by Donelick et al. (2005). Whole rock samples were crushed using a jaw crusher with the minimum jaw separation set to 2-3 mm, sieved through $300 \mu \mathrm{m}$ nylon mesh, and the $<300 \mu \mathrm{m}$ size fraction washed with tap water and allowed to dry at room temperature. Zircon was separated from other mineral species using a combination of lithium metatungstate (density $\sim 2.9 \mathrm{~g} / \mathrm{cm}^{3}$ ), Frantz magnetic separator, diiodomethane (density $\sim 3.3 \mathrm{~g} / \mathrm{cm}^{3}$ ), and hand-panning separation procedures. Epoxy wafers $(\sim 1 \mathrm{~cm} \times 1 \mathrm{~cm}$ ) containing zircon grains for LA-ICP-MS were polished manually using 3.0 $\mu \mathrm{m}$ and $0.3 \mu \mathrm{m} \mathrm{Al}_{2} \mathrm{O}_{3}$ slurries to expose internal zircon grain surfaces. The polished zircon grain surfaces were washed in $5.5 \mathrm{M} \mathrm{HNO}_{3}$ for $20 \mathrm{~s}$ at $21^{\circ} \mathrm{C}$ prior to introduction into the laser system sample cell.

\section{LA-ICP-MS Session Details}

LA-ICP-MS data collection was performed at the Geoanalytical Laboratory, Washington State University, Pullman, Washington, U.S.A. Individual zircon grains were targeted for data collection using a New Wave YP213 $213 \mathrm{~nm}$ solid state laser ablation system using a $20 \mu \mathrm{m}$ diameter laser spot size, $5 \mathrm{~Hz}$ laser firing rate, and ultra-high purity He as the carrier gas. Isotopic analyses of the ablated zircon material were performed using a ThermoScientific Element2 magnetic sector mass spectrometer using high purity $\mathrm{Ar}$ as the plasma gas. The following masses (in amu) were monitored for $0.005 \mathrm{~s}$ each in pulse detection mode: 202, 204, 206, 207, 208, 232, 235, and 238. At time $=0.0 \mathrm{~s}$, the mass spectrometer began monitoring signal intensities; at time $=6.0 \mathrm{~s}$, the laser began ablating zircon material; at time $=30.0 \mathrm{~s}$, the laser was turned off and the mass spectrometer stopped monitoring signal intensities. A total of 250 data scans were collected for each zircon spot analyzed comprising: approximately 55 background scans; approximately 20 transitions scans between background and background+signal, approximately 175 background+signal scans. A scheme was developed to check whether mass 238 experienced a switch from pulse to analog mode during data collection and a correction procedure was employed to ensure the use of good quality intensity data for masses 235 and 238 when such a switch was observed.

\section{U-Pb Data Analysis}

Previous LA-ICP-MS studies of U-Pb zircon dating used the so-called intercept method which assumes that isotopic ratio varies linearly with scan number due solely to linearly varying isotopic fractionation (Chang et al., 2006; Gehrels et al., 2008). The data modeling approach favored here was the modeling of background-corrected signal intensities for each isotope at each scan. Background intensity for each isotope was calculated using a fitted line (for decreasing background intensity) or using the arithmetic mean (for non-decreasing background intensity) at the global minimum of selected isotopes $\left({ }^{206} \mathrm{~Pb},{ }^{232} \mathrm{Th}\right.$, and $\left.{ }^{238} \mathrm{U}\right)$ for the spot. Background+signal intensity for each isotope at each scan was calculated using the median of fitted ( $2^{\text {nd }}$-order polynomial) intensity values for a moving window ( 7 scans wide here) that includes the scan. The precision of each background-corrected signal intensity value was calculated from the precision of background intensity value and the precision of the background+signal intensity value.

Zircon U-Pb age standards used during analysis are summarized in Appendix C, including the $1099 \pm 0.6 \mathrm{Ma}$ FC zircon (FC-1 of Paces and Miller, 1993) used here as the primary age standard. Isotopic data for FC were used to calculate $\mathrm{Pb} / \mathrm{U}$ fractionation factors and their absolute errors for each FC data scan at each FC spot; these fractionation factors were smoothed session-wide for each data scan using the median of fitted ( $1^{\text {st }}$-order polynomial) fractionation factor values for a moving window (11 FC spots wide here) that includes the current FC spot and scan. Under the operating 
conditions of the LA-ICP-MS sessions in this study, fractionation factors were found to vary strongly with scan number, decreasing with increasing scan number (presumably due to increasing ablation pit depth and the effect this had on fractionation, (e.g., Paton et al., 2010). The zircon crystal lattice is widely known to accumulate $\alpha$ radiation damage (e.g., Zhang et al., 2009 and references therein). It was assumed here that increased $\alpha$-damage in a zircon leads to a decrease in the hardness of the zircon; this in turn leads to a faster rate of laser penetration into the zircon during ablation leading to dependence of isotopic fractionation on the degree of zircon lattice radiation damage. Ages calculated for all zircon age standards, when those standards were treated as unknowns, were used to construct a fractionation factor correction curve (exponential form) in terms of accumulated radiation damage. The notion of matrix-matched zircon standard and zircon unknown has been proposed largely on the basis of trace element chemistry (e.g., Black et al., 2004). In this study, time and lattice damage, parameters invisible to instruments used to characterize trace element chemistry, were introduced and applied based on measured $U$ and Th chemistries to effectively matrix-match standard and unknown zircons.

Uranium decay constants and the ${ }^{238} \mathrm{U} / 235 \mathrm{U}$ isotopic ratio reported in Steiger and Jäger (1977) were used in this study. Errors for the isotopic ratios ${ }^{207} \mathrm{~Pb} /{ }^{235} \mathrm{U}_{\mathrm{c}}\left({ }^{235} \mathrm{U}_{\mathrm{c}}=137.88^{238} \mathrm{U}\right),{ }^{206} \mathrm{~Pb} /{ }^{238} \mathrm{U}$, and ${ }^{207} \mathrm{~Pb} /{ }^{206} \mathrm{~Pb}$ at each scan included errors from the background-corrected signal values for each isotope, the fractionation factor error, and an additional relative error term required to force $95 \%$ of the $\mathrm{FC}$ ages to be concordant. Ages for the ratios ${ }^{207} \mathrm{~Pb} /{ }^{235} \mathrm{U}_{\mathrm{c}},{ }^{206} \mathrm{~Pb} /{ }^{238} \mathrm{U}$, and ${ }^{207} \mathrm{~Pb} /{ }^{206} \mathrm{~Pb}$ were calculated for each data scan and checked for concordance; concordance here was defined as overlap of all three ages at the $1 \sigma$ level (the use of $2 \sigma$ level was found to skew the results to include scans with any significant common $\mathrm{Pb}$ ). If the number of concordant data scans for a spot was greater than zero, the more precise age from the concordant-scan-weighted ratio ${ }^{207} \mathrm{~Pb} /{ }^{235} \mathrm{U}_{\mathrm{c}},{ }^{206} \mathrm{~Pb} /{ }^{238} \mathrm{U}$ or ${ }^{207} \mathrm{~Pb} /{ }^{206} \mathrm{~Pb}$ was chosen as the preferred age. Asymmetrical negative-direction and positive-direction age errors were calculated by subtracting and adding, respectively, the isotopic ratio errors in the appropriate age equation (Chew and Donelick, 2012).

\section{Moving-Median Smoothing}

Moving-median smoothing (MMS) is applied here to a subset (window) of $N$ data points $x, y$ of width $m$ values of $x$ to which a polynomial of order $n$ is fitted. For each value of $x$ at each position of the data window, a value of $y$ is calculated for the fitted polynomial. The window is positioned with the right-hand boundary at the left-hand $x$ value and then shifted $\mathrm{N}-1$ times until the left-hand boundary of the window is positioned at the right-hand $x$ value. At each $x$ position, $m$ fitted values of $y$ are calculated and the median of these fitted values is taken. 
APPENDIX C: ZIRCON AGE STANDARDS

\begin{tabular}{|c|c|c|c|}
\hline Standard & Standard & $\mathrm{U}-\mathrm{Pb}$ age $( \pm 2 \sigma)$ & Reference \\
\hline FC & $\begin{array}{l}\text { Duluth } \\
\text { complex }\end{array}$ & $1099.0 \pm 0.6 \mathrm{Ma}$ & Paces and Miller, 1993 \\
\hline F5 & $\begin{array}{l}\text { Duluth } \\
\text { complex }\end{array}$ & $\begin{array}{l}1099.0 \pm 0.6 \mathrm{Ma} \\
\text { (assumed equal to } \\
\mathrm{FC}-1 \text { ) }\end{array}$ & Paces and Miller, 1993 \\
\hline IF & $\begin{array}{l}\text { Fish Canyon } \\
\text { Tuff }\end{array}$ & $28.201 \pm 0.012 \mathrm{Ma}$ & $\begin{array}{l}\text { Lanphere et al., 2001; Kuiper et } \\
\text { al., } 2008\end{array}$ \\
\hline MD & $\begin{array}{l}\text { Mount } \\
\text { Dromedary }\end{array}$ & $99.12 \pm 0.14 \mathrm{Ma}$ & Renne et al., 1998 \\
\hline $\mathrm{PX}$ & Peixe & $563.5 \pm 1.6 \mathrm{Ma}$ & Gehrels et al., 2008 \\
\hline R3 & $\begin{array}{l}\text { Braintree } \\
\text { complex }\end{array}$ & $418.9 \pm 0.4 \mathrm{Ma}$ & Black et al., 2004 \\
\hline $\mathrm{T} 2$ & $\begin{array}{l}\text { Temora 2, } \\
\text { Middledale } \\
\text { gabbroic } \\
\text { diorite }\end{array}$ & $416.78 \pm 0.33 \mathrm{Ma}$ & Black et al., 2004 \\
\hline TR & $\begin{array}{l}\text { Tardree } \\
\text { Rhyolite }\end{array}$ & $61.23 \pm 0.11 \mathrm{Ma}$ & Dave Chew, pers. commun. \\
\hline
\end{tabular}

